Earth Sciences History, Volume 32, 156-185, 2013.

Note that this version of the text may not include all of the final editorial amendments added in proof.

\title{
CHARLES DARWIN, BARTHOLOMEW SULIVAN, AND THE GEOLOGY OF THE FALKLAND ISLANDS: UNFINISHED BUSINESS FROM AN ASYMMETRIC PARTNERSHIP
}

\author{
P. STONE ${ }^{1}$ and A. W. A. RUSHTON ${ }^{2,3}$ \\ ${ }^{1}$ British Geological Survey, Murchison House, West Mains Road, Edinburgh EH9 3LA, UK. \\ psto@bgs.ac.uk \\ ${ }^{2}$ Department of Palaeontology, The Natural History Museum, London SW7 5BD, UK. \\ a.rushton@nhm.ac.uk \\ ${ }^{3}$ British Geological Survey, Keyworth, Nottingham, NG12 5GG, UK.
}

\begin{abstract}
When in 1846 Charles Darwin published the first account of the geology of the Falkland Islands he drew on his experiences in 1833 and 1834 during the voyage of HMS Beagle, and on collections made at that time by the ship's Assistant Surgeon, William Kent. Aboard HMS Beagle Darwin struck up a particular friendship with Lieutenant Bartholomew Sulivan who subsequently revisited the Falklands between 1838 and 1845 in command of HMS Arrow and HMS Philomel. The surviving letters that Sulivan wrote to Darwin during those voyages contain a wealth of additional geological observations. Sulivan also dispatched additional geological specimens to Darwin, one of which can be identified in the extant Beagle collection. Darwin utilised some of Sulivan's structural geology sketches in his 1846 paper, but otherwise the detailed and accurate observations were only partly and ambiguously recorded there in a footnote. Sulivan described fold and cleavage relationships, made the first record of intrusive dolerite dykes in the Falkland Islands, and recorded landforms and lithologies that could have led to the early recognition of both Quaternary and Late Palaeozoic glaciation in the Falklands. Glacial phenomena were not generally understood at the time and Darwin at first misinterpreted some of Sulivan's prescient observations. The acknowledgements in Darwin's 1846 paper do scant justice to Sulivan's contributions which, as a result, have remained generally unappreciated. This paper seeks to rectify that situation whilst reconciling Darwin's account with the modern geological interpretation and reviewing his specimen collections in current terms.
\end{abstract}

\section{INTRODUCTION}


During the 1831-1835 voyage of HMS Beagle, Charles Darwin (1809-1882) devoted much time and energy to investigating the geology of the lands that he visited. Once safely returned to Britain he wrote his classic account of the entire voyage, Journal of Researches into the Geology and Natural History of the Various Countries Visited by HMS 'Beagle' (1839), and detailed his geological observations in a series of books: The Structure and Distribution of Coral Reefs (1842); Geological Observations on the Volcanic Islands Visited during the Voyage of HMS 'Beagle' (1844); and Geological Observations on South America (1846). The geology of only one small area was described independently, a paper titled 'On the geology of the Falkland Islands' being presented at the Geological Society of London’s meeting on 25 March 1846. This was published in the Society's journal later that year (Darwin 1846). The paper was accompanied by another describing the Palaeozoic fossils, mostly brachiopods, which Darwin had discovered there in 1833 (Morris and Sharpe 1846). The importance of Darwin's experiences in the Falkland Islands to the development of his broader scientific ideas, and the details of his geological fieldwork there, have been reviewed by Armstrong (1992) and also touched upon by Herbert (2005, p. 301). In this paper we assess Darwin's geology in comparison with modern work, and investigate the contributions made by others to his geological interpretation of the Falkland Islands, most notably the observations of Bartholomew Sulivan (1810-1890), lieutenant aboard HMS Beagle and later captain of HMS Arrow and HMS Philomel during their subsequent surveying voyages around the Falkland Islands.

HMS Beagle made two visits to the Falkland Islands, first in March 1833 and again in March 1834. Whilst there, the ship was mostly based in Johnson Harbour on the north side of Berkeley Sound, East Falkland, whence Darwin explored East Falkland. On the second visit he made an overland trip on horseback as far as the isthmus joining the main part of East Falkland to its southern sector, Lafonia (see Figure 1). At the beginning of his 1846 paper Darwin made it clear that "[m]y examination was confined to the eastern island; but I have received through the kindness of Captain Sulivan and Mr Kent, numerous specimens from the western island, together with copious notes, sufficient to show the almost perfect uniformity of the whole group”. Darwin's association with Sulivan and Kent started with the famous voyage of HMS Beagle (1831-1836), on which Lieutenant Bartholomew Sulivan was accompanied (from 1833) by Assistant Surgeon William Kent. In his geological notes, written-up whilst still aboard the Beagle, Darwin acknowledged a suite of specimens procured for him from West Falkland by Kent early in 1834. However, in the case of Sulivan, who became a life-long friend of Darwin, a wealth of important geological observations and specimens was acquired much later, during Sulivan's subsequent surveying voyages to the Falklands in command of HMS Arrow (1838-1839) and HMS Philomel (1842-1845). For biographies of Bartholomew Sulivan see Henry N. Sulivan (1896) and David 
(2008); for an obituary see Henry N. Sulivan (1890): Henry Norton Sulivan was Bartholomew's second son (b. 1846).

Sulivan's geological observations were passed on to Darwin in a series of letters that were published in Volumes 2 and 3 of The Correspondence of Charles Darwin (Burkhardt and Smith 1986, 1987) and have more recently been made available online as part of the University of Cambridge Darwin Correspondence Project database. ${ }^{1}$ In both cases, see Letters 429, 675, 730, 886 and 13,847. Some of the letters may be incomplete and they do not represent the entire correspondence since Darwin's replies have not survived and it is not certain that all of Sulivan's letters have done so. However, it is clear that Sulivan observed and described many geological features that were not recognised at the time as being of importance, and which have only been 'rediscovered' in relatively recent times. Apart from their geological content, the extant letters contain much zoological data, with Sulivan responding to requests from Darwin for details of the feral horses, cattle and rabbits and much more besides. There is also general naval and family gossip and descriptions of contemporary events in South America. Whilst the importance of Sulivan's zoological observations to Darwin's developing ideas on natural selection has been noted by several of Darwin's biographers (e.g. Armstrong 1992), Sulivan's prescient geological observations have generally been overlooked.

\section{TOPOGRAPHICAL AND GEOLOGICAL MAPPING}

The Falkland Islands lie in the South Atlantic Ocean around $52^{\circ}$ South, $60^{\circ}$ West. The archipelago is made up of two main components, East and West Falkland, a dozen or so large subsidiary islands, and almost 800 smaller islands, rocks and reefs (see Figure 1). These together add up to a total land area of just over $12000 \mathrm{~km}^{2}$. By the time of Darwin's visits aboard HMS Beagle there had been competing attempts at settlement by Britain, France and Spain, commencing with the French expedition led by Antoine Louis de Bougainville (1729-1811) which established Port Louis in 1764. The navies of all three countries made attempts at coastal survey, and the British charts of the islands which were available to Darwin and to Robert Fitzroy (1805-1865), in command of HMS Beagle, would most probably have been based on survey work in the late 1760s led by Captain John McBride. This phase of Falkland Islands history has been ably summarised by Cawkell (2001, pp. 20-32).

Though the work of Fitzroy's predecessors had produced a broadly satisfactory outline of the main coastal features there were no terrestrial maps of any description at the time of Darwin's visit. The Beagle surveys in 1833 and 1834 added much coastal data, and the marine charts were further improved by

\footnotetext{
http://www.darwinproject.ac.uk.
} 
Sulivan's work from HMS Arrow and HMS Philomel. As part of his surveys, Sulivan triangulated some of the more prominent hilltops, but the absence of accurate terrestrial maps continued for another century, until a comprehensive topographical survey utilising aerial photography was carried out in the 1950s, with the results published as a series of 1:50 000 scale map sheets in 1961 by the British Government's Department of Overseas Surveys. These remain the only comprehensive and publically-available, large-scale maps of the Falkland Islands, but a few areas are still marked 'obscured by clouds'. A revised, 2-sheet compilation at 1:250 000 was produced by the British Ordnance Survey in 1995.

The absence of topographical base maps undoubtedly hindered the geological exploration of the Falkland Islands. Darwin did not attempt to produce a geological map and Sulivan's subsequent ambitions in that field were not fulfilled. Thereafter, some geological observations were made by passing expeditions whose main interests were elsewhere (Stone and Rushton 2012), and it was not until 1902 that serious geological investigation was resumed. In that year, the geologist Johan Gunnar Andersson (1874-1960) spent some time in the Falklands whilst waiting to rendezvous with the ship supporting the 19011903 Swedish South Polar Expedition. Andersson's work in the islands was extended by his colleague Thore Halle, who made considerable progress towards an overall understanding during the Swedish Magellanic Expedition, 1907-1909. His report (Halle 1911) included a geological sketch map that for the first time endeavoured (with partial success) to define the distribution of the main rock units across the entire archipelago. Next, and despite the continuing absence of detailed topographical base maps, an attempt at a regional geological survey was made between 1920 and 1922 by Herbert Arthur Baker (1885-1954) who had been appointed 'Government Geologist'. Baker's survey was primarily a search for economically important minerals and though unsuccessful in that respect his work was comprehensive, thorough and enduring. His geological map and report (Baker 1924) were not superseded for fifty years, until a photogeological reinterpretation by Mary Greenway was published by the British Antarctic Survey (Greenway 1972).

Baker was the first to propose a system of lithostratigraphical nomenclature and the terms that he coined were adapted by Raymond Adie (1958) and Greenway (1972) before being assimilated into a modern, formally defined lithostratigraphy, following field mapping between 1996 and 1998 by Don Aldiss and Emma Edwards. The results of this geological mapping project were published for the Falkland Islands Government by the British Geological Survey as a geological map in two sheets at a scale of 1: 250000 (Aldiss and Edwards 1998) and a substantial geological report of 135 pages (Aldiss and Edwards 1999). The modern interpretation of the solid geology illustrated therein is summarised in Figure 1 and Table 1. The oldest Falkland Islands rocks are the ca 1000 million years old, granite and gneiss of the Proterozoic Cape Meredith 
Complex, which has a very small outcrop on the southernmost point of West Falkland. This 'basement' complex is unconformably overlain by the West Falkland Group, a thick succession of fluvial to neritic and shallow marine, clastic strata ranging in age from Silurian to Devonian or earliest Carboniferous: a fossiliferous unit in the middle of the group (Fox Bay Formation) is early Devonian in age, about 405 million years old. The West Falkland Group underlies most of West Falkland and the northern part of East Falkland. In the southern part of East Falkland a younger succession of strata, the Lafonia Group, has near its base a Permo-Carboniferous glacigenic unit (Fitzroy Tillite Formation) formed about 300 million years ago, which passes upwards into a thick succession of Permian, deltaic and pro-delta basinal strata. The metamorphic and sedimentary rocks are cut by a multitude of Jurassic and Cretaceous dolerite dykes ranging in age between about 190 and 120 million years (Stone et al. 2008; Richards et al. 2013 and references therein). The regolith covering the bedrock was produced by a variety of weathering and periglacial processes and is widely buried beneath several metres of peat.

Both Halle (1911) and Baker (1924) commented on the remarkably close correspondence of Falkland Islands geology with that of South Africa, with Baker invoking continental drift to explain the similarity. However, with continental drift being generally regarded sceptically at that time so things rested, until the South African geologist, Raymond Adie, proposed a radical solution to the mismatched regional geology of the Falkland Islands. In a remarkably prescient contribution, Adie (1952) used the alignment of structural and sedimentological trends to support his proposal that during the Mesozoic opening of the Atlantic Ocean the Falklands had been rotated by $180^{\circ}$ from an original position adjacent to the east coast of South Africa. This solution to the geographical enigma of Falklands geology was completely neglected until it was 'rediscovered' in terms of microplate rotation (Mitchell et al. 1986) once the plate tectonic revolution had swept through geology. It is now widely accepted in principle and recent research (e.g. Trewin et al. 2002, Hunter and Lomas 2003) has refined Adie's model. In general terms, the West Falkland Group and Lafonia Group are now seen as the originally eastward extensions of, respectively, the Cape Fold Belt and the Karoo Basin.

Darwin's geological account of the Falkland Islands, based on his own observations and those subsequently made by Sulivan, proved a sound basis for all of the investigations that followed, culminating in the 1998 and 1999 geological map and report. But there was one other, unrelated, aspect of the Falkland Islands' future for which Darwin's assessment has also proved prescient. His visits took place at a time when Britain had re-established control after a relatively chaotic interval, and the move had not been well received in Buenos Aires. Darwin wrote in his diary on Sunday 24 March 1833, after a fossil-collecting expedition to Port Louis: "The inhabitants are a curious mixed 
race; their habitations are in a miserable condition \& deficient in almost every accommodation. The place bespeaks what it has been, viz a bone of contention between different nations”. In Sulivan's case the conflict with Argentina was real rather than hypothetical. During the austral winters he took HMS Philomel back to the River Plate estuary and joined the British and French naval force defending Montevideo (Uruguay) against a besieging pro-Argentine force; his involvement culminated in the naval battle of Vuelta de Obligado, fought on 20 November 1845, when a combined British-French fleet forced passage along the River Paraná which had been blockaded by the Argentine Confederation.

Though the inhabitants of the Falkland Islands now enjoy a rather more prosperous and comfortable existence, in a British Overseas Territory, the political contention has continued. Relations were, however, sufficiently amicable between 1970 and 1980 for several Argentinian geologists to work in the Falklands, concentrating on local specialist issues rather than regional survey. Their contributions have been summarised by Aldiss and Edwards (1999, p. 5). More recently, Argentina has vigorously revived a historical claim to Las Islas Malvinas, in support of which, a parallel topographical nomenclature has been created (and continues to grow). Whilst Darwin, Fitzroy and Sulivan have been accommodated therein (though the settlement of Darwin was briefly renamed Puerto Santiago during the 1982 military occupation, and Sulivan is usually mis-spelt Sullivan), other Beagle officers have not found favour: so, for example, in the Argentine canon Mount Usborne (see Figure 2) becomes Cerro Alberdi and the Wickham Heights become Las Alturas Rivadavia. Inevitably, the alternative gazetteer (Permanent Committee on Geographical Names 2006) has influenced the lithostratigraphical terminology applied, albeit inconsistently, in the Argentine literature (e.g. Turner 1980, Limarino et al. 1999, Mendía et al. 2008). In the Malvinas archipelago the two main islands become Gran Malvina (West Falkland) and Isla Soledad (East Falkland) and these names are applied to the West Falkland and Lafonia groups respectively; the Cape Meredith Complex is usually renamed Complejo Cabo Belgrano. With Lafonia released, that name sometimes displaces Fitzroy in a Lafonia (or Lafonian) tillite formation, though the tillite does not crop out in Lafonia sensu stricto. During the brief Argentine military occupation of the islands in 1982, the town of Stanley (founded in 1843) and its harbour, Port Stanley, were jointly renamed Puerto Argentino. The usage has been maintained in Argentine literature and accordingly the Port Stanley Formation is commonly (though not invariably) disavowed, Formación Caleta Shag (a partial translation of Shag Cove, a location in 'Gran Malvina') being preferred, after Scasso and Mendía (1985) who pointed out the inappropriateness of the previously applied nomen nudum, Formación Monte María (Turner 1980). Regrettably, the inevitable confusion arising from these and many other alternative usages seems likely to continue. Darwin would probably not have been surprised. 


\section{DARWIN'S STRATIGRAPHY}

In his 1846 paper Darwin described two lithological divisions of sedimentary rock: 'clay-slate with sandstone' that was fossiliferous in places and 'quartzrock'. Along the northern shore of Berkeley Sound he noted the upward transition from the 'quartz rock' into the 'clay-slate', which in modern terms is the transition from the quartzo-feldspathic arenites of the Port Stephens Formation into the micaceous sandstone and mudstone of the Fox Bay Formation. In his 1846 paper he wrote: "I nowhere actually saw the superposition of clay-slate on the quartz, but in several places on the sea-shore I traced the most gradual transitions between these two widely differing formations". Darwin's initial impressions of the Falkland Islands and their geology were not inspiring. That changed after a traverse of the coast from Johnson Harbour to Port Louis as recorded in his diary entry-for this study we have utilised the version edited by Keynes (1988) - for about 16-17 March 1833: "The whole aspect of the Falkland Islands, were however changed to my eyes from that walk; for I found a rock abounding with shells; \& these of the most interesting geological æra”. Darwin would have seen similar rocks and fossils on his Welsh excursion with Adam Sedgwick prior to departing on the Beagle, and now considered his Falklands fossils to be, like the Lower Palaeozoic Welsh examples, from strata of the oldest age likely to contain organic remains. This was interesting in itself in such a remote location, but he was also enthused by the possibility of comparing ancient faunas from different parts of the Globe (Herbert 2005, p. 301). The Falklands fossils occurred in the sandstone beds associated with Darwin's 'clay-slate' division. When eventually assessed by specialists back in Britain (Morris and Sharpe 1846) the fossils were assigned a generalised Silurian to Devonian age. They are now recognised as being of Early Devonian age and are approximately 405 Ma old.

Traversing south from Berkeley Sound, Darwin reached the outcrop of the Port Stanley Formation, the hard, white, quartz-rich sandstones and quartzites that make up the principal range of rocky hills extending from east to west across East Falkland (see Figures 1, 2 and 3). The Port Stanley Formation stratigraphically succeeds the Fox Bay Formation but comprises superficially similar lithologies to those of the Port Stephens Formation. As a result of this similarity, Darwin conflated all the 'quartz-rock' in a single, older division, writing in his 1846 paper: "[f]rom the manner in which the clay-slate and sandstone often come up on each side to the base of the quartz ranges, I have no doubt that this rock is a lower and more arenaceous formation metamorphosed". He considered the structure of the hill range to be broadly anticlinal, and so the misinterpretation was influenced by another conflation of discrete stratigraphical divisions based on the superficial similarity of the lithologies that they contain. In this case, the confusion arose from Darwin's expedition southwards across the principal range of hills (the Port Stanley Formation) towards Lafonia. He 
camped in the vicinity of the subsequently-established settlement now named after him (see Figures 1 and 2), and was there surrounded by sub-horizontal beds of micaceous, fine-grained sandstone and mudstone of Permian age, in modern lithostratigraphical terms part of the Brenton Loch Formation, Lafonia Group. However, he associated these rocks with the somewhat similar-looking, though Devonian, Fox Bay Formation beds to the north of the hills at Berkeley Sound, and included all within his division of 'clay-slate and sandstone'.

Darwin's interpretation of the stratigraphy is understandable, and indeed the detail of the relationships was not resolved for another 150 years. Andersson (1907) first realised the Permian age of the Lafonia Group when he discovered that it contained a fossil Glossopteris flora. Subsequently, Halle (1911) established that the fossiliferous, Devonian micaceous sandstone division (Fox Bay Formation) separated the two different (though of similar appearance) divisions of quartz-rich sandstone. Halle's interpretation drew principally on evidence from West Falkland and he erroneously suggested that all of Darwin's 'quartz-rock' in East Falkland might be younger than his 'clay-slate and sandstone', the opposite relationship to that proposed by Darwin. In the first attempt at an extensive geological assessment Baker (1924) followed the same interpretation, and the first comprehensive geological map of the Falkland Islands - the photogeological compilation of Greenway (1972)—also shows the northern part of East Falkland, north of Berkeley Sound, as being underlain by the Port Stanley Formation. Curiously, Greenway (1972, p. 15) cites Darwin (1846) in support of such an interpretation. Darwin's original assessment of that area of East Falkland, with the Port Stephens Formation underlying the Fox Bay Formation, was not vindicated until the modern ground survey carried out between 1996 and 1998 by Aldiss and Edwards (1999).

\section{THE SPECIMEN COLLECTIONS}

The geological specimens collected in the Falkland Islands by Darwin are now divided between The Natural History Museum (NHM) in London, and the Sedgwick Museum (SM) in Cambridge, and have been registered with accession numbers appropriate to those museums' collections. Most of the fossil specimens are held by the NHM, whilst the rock specimens (and most of the other Beagle rocks) are held by the SM, which also has a few fossil specimens. Darwin's notes in his 'geological diary' (van Whye 2002) describe eighty-four geological specimens from the Falkland Islands, but about ninety unambiguously 'Darwin' specimens are apparently present in the combined museum collections. The uncertainty arises from the likely division of some original specimens and the inconsistent numbering of part-counterpart pairs; the figure does not include either the Sharpe or the Etheridge (NHM) material

discussed below. Though the specimens were collected in two batches, in 1833 and 1834 respectively, all but one would have had labels within Darwin's red 
series: those collected in 1833 were assigned numbers between 1078 and 1152; those collected in 1834 are numbered between 1886 and 1946, with one additional specimen, 2058, which would have been in the green label series. Only a few of the original labels have survived so that not many of the NHM fossil specimens can now be associated with the numbers originally allocated by Darwin; these are identified in Appendix 1 wherein the NHM collection is summarised. Though the rock specimens in the SM have been relabelled, the new labels still carry Darwin's original Beagle collection number, as listed in Appendix 2 where the SM collection is summarised.

On his return to Britain, Darwin's fossils were identified and formally described in a paper published by the Geological Society of London (Morris and Sharpe, 1846) for which Darwin wrote an introductory account of Falkland Islands geology (Darwin 1846). John Morris (1810-1886) and Daniel Sharpe (18061856) were amongst the leading British palaeontologists of their time and from Darwin's collection they described nine species of brachiopods, a bivalve, crinoid columnals and fragmentary trilobite remains. We have not found a convincing bivalve in the extant specimens but, in addition to the taxa listed, we have noted a bellerophontid gastropod that has not been previously recorded. After their description, the key specimens passed into the care of the Museum of Practical Geology (MPG), the Geological Survey's museum, established in 1841. They moved to their present home at The Natural History Museum in 1880, following the establishment of that institution as a separate branch of the British Museum. At first, the new museum was known as the British Museum (Natural History) and only became an independent entity, and The Natural History Museum, as recently as 1965 . For simplicity, in this account we will refer to it consistently as The Natural History Museum (NHM) irrespective of any resulting anachronism.

When Darwin's Falklands fossils arrived in 1880 from the MPG, they were neither the first nor the last of his specimens from those remote islands to come into the NHM's collection. Both John Morris and Daniel Sharpe were avid fossil collectors and both had assimilated some of Darwin's examples into their own collections. The Morris Collection arrived at the NHM in 1867 and the three Darwin specimens that it contained became the first fossils from the Falkland Islands to be lodged there (see Figure 4); they were re-united with the main collection in 1880. The Sharpe Collection passed to the Geological Society of London in 1856 on the death of Daniel Sharpe, but was then transferred to the NHM in 1911 when the Geological Society’s collection was dispersed. The Sharpe collection contained about a dozen Falkland Islands specimens, some in several parts and all relatively small. Most have the appearance of flakes removed from larger specimens to facilitate detailed examination of the original material. Their provenance is confirmed by manuscript notes accompanying 
some of the specimens that acknowledge 'C. Darwin Esq.' (Stone and Rushton 2012, see Figure 5).

Though unproven, it is possible that another collector, Robert Etheridge $\mathrm{Sr}$ (1819-1903), had also acquired two of Darwin's specimens and passed them to the NHM in 1869 as part of his own collection (Stone and Rushton 2012, see Figure 4). At the time, Etheridge was Palaeontologist to HM Geological Survey and was based at the Museum of Practical Geology. His interest in Darwin's specimens was confirmed in 1985 when The Geological Museum, successor to the MPG, passed from the stewardship of the British Geological Survey and was assimilated by the NHM. Unregistered foreign material transferred to the NHM, according to a palaeontologist involved in the move, included "two trays of Darwin specimens used by Etheridge" (Adrian Morter, personal communication, 29 June 2012). We are confident that none of the specimens transferred in 1985 were from the Falklands Islands, but if Etheridge's specimens presented in 1869 did not originate with Darwin, their provenance is uncertain.

Neither Darwin (1846) nor Morris and Sharpe (1846) referred to specific collecting sites in the Falkland Islands, but Darwin's diary and notebooks make it clear that all of the fossils that he collected in the Falkland Islands came from the area around Berkeley Sound, East Falkland, However, one specimen in the NHM's Darwin collection is noteworthy as having been found not at Berkeley Sound but at Burnt Harbour, a location on Saunders Island off the north coast of West Falkland (see Figure 1) by Bartholomew Sulivan. The Saunders Island specimen has no connection to the Beagle expedition, and was in fact collected by Sulivan more than ten years later, during the 1844-1845 austral summer when he was again surveying around the Falkland Islands in command of HMS Philomel (Stone and Rushton 2012). This is made clear in two letters that he wrote to Darwin (Darwin Correspondence Project Database, Letters 730 and 886). In the first, dated 13 January to 12 February 1845, Sulivan describes fossils he had found on the south side of Saunders Island, "They are only casts of shells but are very numerous being 15 in number on one bit of stone about 15 square inches". He included a small sketch of an Australocoelia (originally Atrypa) palmata. His account perfectly matches the specimen (Stone and Rushton 2012, see Figure 3a) and it was most probably Sulivan who scratched the inscription "Burnt Harb, Saunders Is" on the back of the fossiliferous slab (Stone and Rushton, 2012, see Figure 3b). In the second letter, written from Montevideo and dated 4 July 1845, Sulivan told Darwin that he was sending a box containing South American fossils but including those "from Saunders Island near Port Egmont further to the Westward than any I had before found". The specimen would have arrived just in time to be included in Morris and Sharpe's description of the Falkland Islands fossils, presented at a meeting of the Geological Society of London on 25 March 1846, and was figured in their subsequent paper (NHM specimen number B.17821, see Appendix 1). 
During his exploration of West Falkland, Sulivan also reported (in letter 675) having found, in White Rock Bay "a sandstone more resembling that of Berkeley Sound and in it are fossil worms". The Fox Bay Formation crops out in the vicinity of White Rock Bay, where Sulivan's 'fossil worms' might possibly have been trace fossils. Meandering trails are preserved on some bedding surfaces in the Fox Bay Formation and locally beds have been extensively bioturbated; in either case the preserved trace fossils could be described as worm-like (see Figures 5 and 6). Sulivan noted that the 'worms' were accompanied by a few of the familiar shells that "appear to me to resemble those in the Berkeley Sound sandstone”. Though he sent specimens back to Darwin they are not to be found in either of the extant collections. If the association with trace fossils is valid then Sulivan's identification of 'worms', whilst not strictly correct, was closer to the truth than the consensus geological opinion of the time, which regarded most trace fossils as the impressions of fucoid seaweeds, rather than the work of marine animals.

One other aspect of Sulivan's palaeontological work in the Falklands is noteworthy. Around what is now Port Philomel he described "an extensive sandstone formation different from all the others" by virtue of being "more compact ... and of a dark Colour but generally a dirty Yellow, having black lines apparently of some vegetable origin in it”. This unit is now defined as the Port Philomel Formation. It succeeds the Fox Bay Formation and is characterised by the presence of fragmentary plant remains (Aldiss and Edwards 1999). Sulivan would have been unaware that he was describing plant fossils, amongst the oldest then known - and Darwin overlooked the importance of his observation. It is appropriate, if fortuitous, that this sedimentary division now celebrates HMS Philomel.

The characteristics of the fossil specimens now held by the NHM are summarised in Appendix 1. Morris and Sharpe (1846) defined eight new brachiopod species: three assigned to each of the genera Orthis and Spirifer, and one assigned to each of Chonetes and Atrypa. All of these genera have been subsequently revised. The modern terminology is appended in Table 2. Modern practice is to conflate all of the spiriferids into a single species, whilst the fate of Orthis tenuis is unresolved. In a comprehensive review of the Falklands Devonian fauna, John Clarke (1913, 285-286) implied that O. tenuis should be synonymised with another of Morris and Sharpe's species, Orthis concinna. But Clarke did not inspect Darwin's specimens and based his view on the published illustrations. Clarke then reassigned $O$. concinna to the genus Leptostrophia and, using other Falkland Islands material that he had acquired, he very tentatively defined a new species of that genus as " $L$ ?? mesembria", now Australostrophia mesembria. Darwin's type specimens of $O$. tenuis in the NHM have been relabelled by an unknown hand as "probably Australostrophia mesembria 
(Clarke)". Depending on the accuracy of the various identifications, this raises issues of priority and/or synonymy. But these are beyond the scope of the present paper.

In addition to the determined brachiopods, Morris and Sharpe (1846) mentioned a ninth brachiopod (an undetermined Orbiculoidea), abundant crionoid ossicles, a bivalve (described as an Avicula), and a trilobite fragment. We have not been able to locate an unambiguous bivalve amongst the fossil specimens but the impression of a calmoniid trilobite thorax is present in NHM specimen B.17790, which also carries Darwin's red series Number 113 (see Appendix 1). Not previously recorded is a small bellerophontid gastropod (probably Plectonotus sp.) present in NHM specimen B.15657. Morris and Sharpe were only prepared to give a generalised 'Silurian to Devonian' age for the assemblage but, as noted by Herbert (2005, p. 301), Murchison was bolder and initially suggested a position in the lower part of his Silurian System, before revising the age to Upper Silurian or Devonian (Murchison 1859, p. 455). The Devonian age is now the consensus, within the Pragian to Emsian stages.

A curious comment in Darwin's geological diary notes (p. 167) refers to "numerous casts which appeared to have been formed by some coral, such as Gorgonia" and goes on to say that the "casts occur in particular seams in the sandstone \& sometimes in such quantity, that the rock is wholly composed of them". No corals of any sort feature in the Falklands Devonian fauna, and Darwin made no further references to Gorgonia in his published work, but six of the SM specimens from Johnson Harbour were originally labelled as such (Darwin specimen numbers 1939-1944, 1939 and 1942 are part and counterpart; see Appendix 2, the numbers indicate that the material was collected during the 1834 visit). The details on the original SM label were presumably copied from Darwin's notes, but the identification was subsequently revised to 'Bryozoa', and when displayed in the SM the specimens were correctly described as crinoids. Examples are shown in Figure 7, with Darwin's Gorgonia proving to be articulated fragments of thin and, in some cases, branching crinoid arms associated with pieces of the column (stem). Oddly, he correctly identified as crinoids the widespread, disarticulated ossicles derived from the column of the animal.

The fossil specimens from Darwin's Falkland Islands collection now held by the SM were retained by Darwin during his lifetime and then, along with most of his rock specimens, they were donated to Cambridge University by his second son, George, in 1897, fifteen years after Charles’ death (Anderson 2009). The Sedgwick Museum fossil specimens are less impressive than most of those in the NHM collection, and were probably the examples not selected for close examination by Morris and Sharpe. The six specimens illustrating 'Gorgonia' 
are registered not as fossils, but as rock specimens within the SM's Harker Collection (see Appendix 2).

Like the fossils, the rock specimens held in Cambridge by the SM were collected in two batches, a year apart. Darwin collected all his own rock specimens from the Berkeley Sound district of East Falkland, but at the beginning of the 1834 visit the Beagle made a rendezvous in Berkeley Sound with the Adventure, a small vessel that had been acquired in the previous year by Fitzroy to increase his expedition's survey capacity. The Adventure had preceded the Beagle back to the Falklands and had spent time surveying around West Falkland. Aboard the Adventure was Assistant Surgeon William Kent who had only joined the Beagle in 1833, in Montevideo. Kent would have had no time in which to strike up a particular friendship with Darwin, and his specimen collecting would have been in response to a formal request for assistance; it was the sort of thing that naval surgeons were expected to do and there was no subsequent, post-Beagle correspondence between the two men. Kent provided Darwin with several specimens of clastic sedimentary rock that he had picked up from the western part of the archipelago. Of these, Darwin retained specimens from Cape Meredith (No. 1890) and New Island (Nos 1886-1889); for these and subsequent localities see Figure 1. In relation to the New Island locality, Darwin's handwriting sometimes appears to read 'Drew Island', but there is no 'Drew Island' and Darwin's geographical description (and the lithology of the specimens) matches New Island. Kent also provided specimens from West Point Island and Port Egmont but although these were referred to by Darwin in his geological notes they were not assimilated into his collection. One curiosity brought back by Kent from the Cape Meredith area was a fragment of fresh-looking, black, highly vesicular basalt (No. 1891), described in the SM register as 'scoriae, picked up on beach'. Though he retained the specimen, Darwin was presumably aware of its likely exotic origin (see Appendix 2) given that he made no mention of the specimen in the context of the Mesozoic dolerite dykes subsequently discovered by Sulivan (see Section 7). Subsequent investigations have shown that vesicular dykes are extremely rare.

Darwin related most of Kent's specimens to the 'quartz-rock' series, though we can now differentiate those from Cape Meredith and New Island as belonging to the Port Stephens Formation, whereas those from West Point Island came from the Port Stanley Formation. The specimen from Port Egmont was probably acquired later than the others since its number, 2058, is isolated from Darwin's other geological specimens from the Falklands, within his green label series. It was described by Darwin as "hard compact dark brown micaceous sandstone of intermediate character". By this he presumably meant intermediate between the 'quartz-rock' and the 'clay-slate with sandstone'. Around Port Egmont (see Figure 1) is exposed the succession from the Fox Bay Formation up through the 
Port Philomel Formation and into the Port Stanley Formation. The first named of these seems most likely to have been the source of specimen No. 2058.

One other specimen procured by Kent may have been the one referred to in Darwin's geological diary comment (p. 193) that “[f]rom a small I ${ }^{\text {sd }}$ (Eagle I ${ }^{\text {sd }}$ ) on the south coast, a specimen of coarse compact blue clay-slate was brought to me”. Eagle Island is now known as Speedwell Island (see Figure 1) and is composed of Permian strata assigned, in the modern lithostratigraphy, to the Bay of Harbours Formation, Lafonia Group. Like the Lafonia Group strata that he would have seen on his southern journey, Darwin conflated this rock with the Devonian 'clay-slate' exposed around Berkeley Sound. We can only regret that he did not discover the Permian 'Glossopteris' flora that is widely present in the Lafonia Group beds, including those exposed on Speedwell Island.

\section{GEOLOGICAL STRUCTURE}

Darwin was much impressed by the complexity of the structure that he observed, particularly in the rugged 'quartz-rock' hills to the south of Berkeley Sound, though he considered the structure there to be broadly anticlinal. He was also struck by the uniformity of the cleavage attitude in the finer-grained, 'clayslate' lithologies, despite its interruption by the interbedded sandstone layers. Darwin's observations of geological structure in the Falkland Islands have been assessed in detail by Armstrong (1992) but it is noteworthy that when Darwin came to publish his account of Falklands geology in 1846 he drew heavily on the subsequent observations of Bartholomew Sulivan

Sulivan's Letter 429 was written from HMS Arrow and is dated 20 October 1838. It is clear from his comments that Sulivan had been attempting to visit specific localities in the area around Berkeley Sound for which Darwin had requested information supplementary to that collected during the Beagle expedition. In addition, Sulivan described how he had set out to construct crosssections of the geological structures seen in the hills that he traversed: "I have begun to make a little section of every range I cross, and I will try to colour a chart at each place I go to"map of the islands. The fruits of this labour, dated variously between November 1838 and April 1839, were consolidated into a single document identified in the database as Letter 13847 and described there as 'possibly incomplete'.

Numerous sketches of geological structures are included and three of them were utilised by Darwin in his 1846 paper. The difference in style between Darwin's cross sections from his Beagle visits, and those drawn by Sulivan is instructive. Darwin's drawings are simplified and diagrammatic, omitting minor complications to illustrate better the fundamental issues, whereas Sulivan attempts to record every last detail and nuance of the rock structure. One of the sketches used by Darwin (Figure 1 in the 1846 paper) usefully demonstrates the 
acuteness of Sulivan's observations. In this drawing of folded strata "in a cliff on the southern coast" (of East Falkland, most probably in the vicinity of Fitzroy) Sulivan has carefully recorded the precise relationships of bedding and cleavage (see Figure 8), illustrating the refraction across different lithological layers of an axial-planar cleavage. In the mid-nineteenth century such relationships were largely unappreciated and in his paper Darwin noted: "I have never myself seen an instance of this structure, and I believe it is a new and interesting case”.

Darwin's description of this illustration of cleavage refraction as a "new and interesting case" would have been written with some authority. His observations of regional cleavage patterns in South America were amongst the first of their kind and his work was much cited by those of his peers who were only then beginning to get to grips with that aspect of structural geology. A good example is provided by Sharpe (1847, pp. 88-89) who, writing On Slaty Cleavage, noted that "Mr Darwin is the only geologist who appears to have sought for order in the arrangement of the dip of the cleavage planes". Sharpe may not have been completely correct in his description of Darwin's uniqueness, but his accolade does emphasise that Darwin was regarded as a leading structural geologist. Sharpe's position in the debate is also interesting. He was one of the two palaeontologists who had described Darwin's fossil collection from the Falklands (Morris and Sharpe 1846) and had become interested in the way in which fossils were tectonically deformed in association with the development of a cleavage in the host rock. Though Sharpe used English examples in his 1847 paper, he would certainly have noted the slight tectonic deformation evident in many of Darwin's specimens from the Falkland Islands.

Towards the end of the Arrow survey, Sulivan had realised that the geological structure became markedly simpler in the southern part of East Falkland, and in his first letter to Darwin from HMS Philomel (Letter 675, written from Montevideo at the end of the survey season and dated 10 May 1843) he confirms that the whole of Lafonia is underlain by relatively flat-lying strata, in contrast to the folded and cleaved rocks seen farther north. Otherwise, the observations made during the Philomel surveys relate to West Falkland. There, Sulivan noted the unusual NNE-SSW trend of the Coast Ridge, contrasting it to the east-west trend of the more northerly West Falkland upland ranges, and the less well-defined arrangement of hills in the south of that island. These trends reflect the fundamentally different geological structures of East and West Falkland and although Sulivan's observations were noted by Darwin in his 1846 paper, he does not appear to have appreciated their broader significance for the regional geological structure of the Falkland Islands.

\section{RECENT AND ANCIENT GLACIATIONS}




\subsection{Cirque glaciation}

On both East and West Falkland, Sulivan climbed many of the highest peaks to establish triangulation stations for his survey. In Letter 675 he described climbing to the highest point on West Falkland, which he named Mount Beaufort (but which is now known as Mount Adam), and expressed astonishment at features found there and at another nearby peak, either the subsidiary summit to the north-north-east (Mount Donald) or perhaps Shingly Mountain to the south-east (see Figure 9a). Sulivan inserted a sketch map of the feature at the summit of 'Mount Beaufort' into the letter (see Figure 9b) and described it as follows; the quotation is taken verbatim from Letter 675:

The most remarkable thing is that the summits of the two highest mountains are both semicircular resembling the half of a Crater and both are open to the NE. Mount Beaufort is very remarkable ... The Summit for nearly half a mile along the edge of the Cliff is nearly level the Cliff has fallen away till it has deposited a slope of fragments very steep reaching to within 10 feet of the summit, and about 200 feet down forming one Edge of a small deep lake outside of which is a mound very little higher than the water. This mound seems to have been a large mass of the Cliff which has fallen outwards leaving a hollow inside which hollow forms the lake.

Sulivan has described, perfectly, a glacially eroded cirque now occupied by a small lake dammed by a terminal moraine ridge.

Darwin would probably have received this description in the British summer of 1843. In the previous year he had revisited sites in North Wales to examine them in the light of ideas of glaciation then gaining scientific credence, so was certainly interested in the subject and familiar with the debate then current (e.g. Herbert 2005, pp. 280-284). However, cirques were not then regarded as having a definitively glacial origin and the Falklands example described by Sulivan was forgotten. The evidence for cirque glaciation in the Falklands was then rediscovered in the late 1960s (Dodds 1969; Clapperton 1971) with about thirtyfive glacial cirques soon identified from the highest parts of both East and West Falkland (Greenway 1972).

\subsection{The stone runs}

Glacial, or rather periglacial activity is now held responsible for another striking feature of the Falklands landscape: the stone runs (see Figure 10). These are blockfields formed almost exclusively of large quartzite boulders derived from the Port Stanley Formation. They had excited Darwin's interest and puzzled him in equal measure. He was familiar with the previously published description by 
Pernety (1771), a naturalist-priest accompanying Bougainville’s French expedition who had speculated that the quartzite boulders had been shaken together by earthquakes. Darwin found this explanation unsatisfactory, particularly when he could find nobody familiar with the islands who had experienced the slightest tremor, but he could think of no better alternative. Armstrong (1992, pp. 80-82) has noted that Darwin hinted, perhaps unwittingly, at a glacially-related origin in cryptic field notes such as "Degradation of land by snow??” but then confirmed his uncertainty in his Journal of Researches (1839, p. 200), writing: “[T]he progress of knowledge will probably some day give a simple explanation of this phenomenon, as it already has of the so longthought inexplicable transportal of the erratic boulders, which are strewed over the plains of Europe”.

Soon after arriving in Berkeley Sound aboard HMS Arrow (on 15 October 1838) Sulivan trekked south to the 'great valley of fragments' described by Darwin in his Journal of Researches (1839, pp. 198-200). It is the largest of the Falkland Islands stone runs and is now known as 'Princes Street'. In Letter 429 Sulivan wrote: "I sat on a rock overlooking the Fragments for some time and tried to form Theories by whole sale but they all ended in smoke”. Nevertheless, Sulivan did note the slightly rounded edges of many blocks, the relationship of the stone runs to the neighbouring quartzite cliffs and he appears to have been the first to note the striped appearance of some of the stone runs, with strips occupied by quartzite boulders alternating with vegetated strips. It has always been something of a puzzle that despite his interest in the stone runs Darwin made no mention of the spectacular striped patterns developed in many places. Sulivan compared their regularity to the "waves of the sea beach" and in his letter to Darwin, which included a rough sketch, he added "now I daresay you know all this but as I do not recollect it in your description I mention it”.

Despite receiving Sulivan's new observations, Darwin did not readdress the problem of the stone runs' origin and the periglacial genesis was not firmly established until the features were examined in detail by Andersson (1906, 1907) during the course of the 1901-1903 Swedish South Polar Expedition. Nevertheless, Darwin may have unknowingly initiated the periglacial explanation during correspondence with the prominent Scottish geologist James Geikie (1839-1915) between 1876 and 1880 (Armstrong 1992, pp. 80-82). Geikie was interested in Darwin's observations of unusual 'drift' deposits in southern England (Geikie 1881, pp. 141-142) and the Falklands stone runs were also discussed in the context of glacial deposits; in one letter (No. 12909 dated 13 December 1880) Darwin confessed that "Ever since seeing the "Streams of Stones' at the Falkland Islands - I have felt uneasy in my mind on this subject”. Geikie then cited Darwin's account of these features in the third edition of his influential book The Great Ice Age (Geikie 1894, pp. 722-723). There, Geikie wrote: 
I do not think there can be much doubt that the 'stone-rivers' of the Falkland Islands are of the same nature and origin as the rubble-drifts already described in connection with the glacial phenomenon of Europe . . . [T] hey seem to be quite comparable to the ... sheets of rock rubbish known as 'head' and 'coombe rock' in England.

In his definitive account, Andersson (1906) acknowledged Geikie's suggestion, but the latter's interest may well have been provoked by the interpretation published after the Challenger oceanographic expedition (1872-1876) by Sir C. Wyville Thomson. After visiting the Falklands and examining the stone runs Thomson (1877, pp. 245-247) described their origin in terms of mass wasting facilitated by a water-saturated peaty soil that he assumed must once have underlain the quartzite boulders. Provocatively, Thomson ended his piece with the words:

I fear that the extreme glacialists will see in it [Thomson's interpretation] a danger to this universal application of their beloved theory to all cases of scratching and grooving. I have known too much of the action of ice to have the slightest doubt of its power; but I say that ice had no hand whatever in the production of these grand 'moraines' in the Falkland Islands.

As a leading 'glacialist', Geikie may well have felt obliged to take up the challenge. He would have been personally familiar with Thomson as a fellowmember of the Edinburgh scientific elite; Darwin provided both men with testimonials in support of their respective applications for professorships at Edinburgh University.

\subsection{The Fitzroy Tillite Formation}

An unappreciated glacial origin was also inherent in Sulivan's descriptions of unusual conglomeratic lithologies from both East and West Falkland. He first mentions having seen a 'porphyritic sandstone' around Fitzroy in letter 675 written from HMS Philomel, but the sighting appears to have been made towards the end of his earlier survey work on HMS Arrow. Aboard the Philomel, Sulivan had put into Port Sussex (on the west coast of East Falkland) and noted the same rock type. The term 'porphyritic' would normally be applied to a fine-grained igneous rock containing a scattering of large, isolated crystals, but here Sulivan was using the term to describe a sedimentary sandstone containing isolated pebbles of quartzite and granite. Later in Letter 675 he described a similar rock from the south side of Byron Sound, West Falkland, as follows: 
[I]t is nearly a hard clay, the colour yellow in one part \& blue in another, yet every where containing boulders \& Pebbles, of other rocks not found in the Islands-I never saw such a variety-beach at the foot of the low cliff is strewed with Pebbles of all sizes ... from a marble to two or three feet in diameter. All appear to be primitive rocks. Granites of all shades and colours kneiss (I forget how to spell it) syanite (sic) and I know not what slate, basalt (at least I think so) \&c \&c. The cliff crumbles away fast and can almost be dug with a spade the Rock is so soft.

This is a perfect description of the now well-known cliff section exposing the glacigenic Fitzroy Tillite Formation at Hill Cove on the north coast of West Falkland (see Figures 1 and 11). Comparing this tillite occurrence with those on East Falkland, Sulivan continued:

This formation has some resemblance to that at the head of Port Fitz Roy containing granite and other Pebbles and which extends along the Flank of Mount Wickham Range to the Westward, but I do not think it is exactly the same. The Pebbles are larger the rock less compact and the variety of rocks much greater.

Once again, Sulivan's observations are notable for their accuracy and insight, with the differences that he recorded between East and West Falkland still fundamental to modern interpretations of this unit. His comment that the deposit contains "rocks not found in the Islands" is also important since it demonstrated a linking of disparate observations and the beginnings of an interest in the genesis of the rocks that he was describing. Even though he was unaware of the existence of the Cape Meredith Complex (it was not discovered until 1902, by J. G. Andersson) Sulivan was quite right in his supposition, and it is now believed that the Fitzroy Tillite Formation contains glacial erratics from as far afield as the area now comprising the Transantarctic Mountains (Stone and Thomson 2005, Stone et al. 2012) that were transported during an ice age approximately 300 million years ago. At the time all of the southern continents were joined into the enormous Gondwana 'supercontinent', and traces of coeval glacigenic rock units are preserved in all of them: for example the Dwyka Tillite in South Africa; the Crashsite Conglomerate in the Ellsworth Mountains, Antarctica; and the Sauce Grande Formation in Argentina, South America. The Falklands example, as so accurately described by Sulivan, was not rediscovered and correctly associated with this glacial episode until the early twentieth century (Halle 1911). It was another fifty years before the differences that Sulivan had noted between East and West Falkland were rediscovered and interpreted in terms of different glacial environments: a terrestrial ice sheet in the west; and glaciomarine deposition beneath a floating ice sheet in the east (Frakes and Crowell 1967). 
During the Beagle voyage Darwin had taken an interest in the distribution of pebble lithologies and in the Falklands had arranged that William Kent should collect beach pebbles from West Falkland. Kent duly acquired material from White Rock Bay, in the northeast of West Falkland which Darwin, in his geological notebook, compared to "the shingle which covers in so immense a sheet, the plain of Patagonia”. Darwin was particularly struck by the apparent similarity of some porphyritic igneous lithologies from White Rock Bay to the pebbles he had seen in Patagonia, and this memory may have coloured his interpretation of Sulivan's account. In the footnote to his 1846 paper Darwin equivocated, referring both to "conglomerate" and "boulder formations" as follows:

Captain Sulivan seems to have found on the western island subordinate beds of a conglomerate or coarse grauwacke. On this island there appear also to be traces of [T] ertiary and boulder formations, corresponding with those of Tierra del Fuego.

It is not absolutely clear which of Sulivan's reports Darwin is here acknowledging, and the reference to Tertiary beds may even have been intended, by analogy with South America, to cover Sulivan's description of the plant-bearing sandstones now identified as the Devonian Port Philomel Formation. What is clear is that Darwin initially misunderstood the description of the important Hill Cove site, since Sulivan returned to the subject in a later letter (No. 730, dated between 13 January and 12 February 1845) wherein he attempted to correct errors in a reply from Darwin that has not survived. Sulivan wrote: "You say it is the 'Ice formation', and suppose it to be on the South side of the Islands. It is quite the contrary".

Darwin's interpretation is revealed by his reported use of 'ice formation'. From his Beagle observations around Patagonia, Darwin had concluded that erratic pebbles and boulders were carried onto shorelines at times of higher relative sea level, by icebergs and drifting floes (Darwin 1842a). From that point of view it was natural that he should suppose the Falklands deposit to be on the south coast, where Antarctic ice might be expected to arrive. The apparent softness of the rock described by Sulivan from the Hill Cove section (actually a local phenomenon arising from weathering and an unusually low level of metamorphism) would also have misled Darwin into assuming that the deposit was of relatively recent origin. Paradoxically, in view of the subsequentlyestablished glacigenic origin of the Fitzroy Tillite Formation, Darwin's ‘ice formation' interpretation was closer to the truth than Sulivan might have thought.

\section{INTRUSIVE DOLERITE DYKES}


Arguably, the single most important new discovery recognised by Sulivan and passed on to Darwin was the presence of intrusive dolerite dyke swarms in West Falkland. This was a completely new aspect, hardly done justice by the footnote to Darwin's 1846 paper noting that "Captain Sulivan observed on the western island numerous basaltic dykes". It has previously been supposed that Sulivan reported the presence of dykes to Darwin during the Beagle expedition (Aldiss and Edwards 1999, Greenway 1972), but the correspondence discussed here makes it clear that the discovery was made later, during the surveys by HMS Philomel.

All of the dyke descriptions came in Letter 730, first with specific reference to dykes cutting the quartzose sandstones of New Island and Weddell Island (though Sulivan referred to Weddell by its original name of Swan Island). However, Sulivan noted that he had been observing the features more widely for some time, but had only recently become convinced of their origin. He wrote as follows, with an accurate description of the effects of thermal metamorphism on the host sandstone beds.

One reason that made me doubtful before about the dykes being Igneous was, that the rock on each side was so little altered (though for some inches it was decidedly so) and where the vein had fallen out the two sides or walls of the crevice stuck up in this manner [see sketch reproduced in Figure 12a] and were very much harder than the rest of the sandstone but only for two or three inches.

He also described the characteristic spheroidal weathering style of the dolerite, likening the appearance of the spreads of rounded boulders to "a pile of shot".

Sulivan recorded "[n]umerous dykes running perpendicular in a North and South direction" but also included in the letter a sketch showing a dyke cutting obliquely across the strata exposed in the cliffs of a small island (Figure 12b), to which he dispatched a boat so that a specimen of the dyke could be recovered. Later in the letter he commented that "there are hundreds of these dykes running miles in length . . . and some are twenty feet wide, and all sizes from that down to two inches”. It is unclear whether or not Darwin saw Sulivan's dyke specimens, which we have not been able to locate. However, with only Darwin's vague footnote in his 1846 paper as a published guide, the full extent of the West Falkland dyke swarm remained unappreciated and did not become apparent until more detailed geological investigations in the early to middle twentieth century, when Greenway (1972) conservatively recorded between three and four hundred, mostly in West Falkland. The ages of the dykes are now known to range between about 190 and 120 million years (Stone et al. 2008; Richards et al. 2013 and references therein). They form several discrete but intersecting swarms. 


\section{EPILOGUE}

Though Charles Darwin is correctly credited with providing the first scientific account of Falkland Islands geology, based on his observations there in 1833 and 1834 during the voyage of HMS Beagle, it is clear from their correspondence that the discovery of some important features, and much relevant detail, arose from the post-Beagle observations made by Bartholomew Sulivan. Sulivan had served under Fitzroy on the first survey voyage of HMS Beagle around the coast of South America (the Falkland Islands were not visited) and for the second voyage, which would carry Charles Darwin. Fitzroy specifically requested that Sulivan be assigned to the ship, describing him as "an excellent observer, calculator and surveyor” (Sulivan 1896, p. 49). Sulivan's interest in geology was most probably sparked by contact with Darwin during the voyage, and by its end the two men had become firm, life-long friends. But Sulivan's ship-management and surveying duties aboard the Beagle would have left him with little opportunity for extra-curricular activities. Once in command of his own ship he was better able to set his own agenda. Initially, during the Arrow survey, Sulivan was mostly seeking answers to questions posed in advance by Darwin. Later, during the Philomel surveys, Sulivan's interests broadened and he began to feed new information to Darwin that was unconnected to anything that had been previously seen or discussed between them. Attention to detail would have been a necessary skill for a naval surveyor, and this attribute is clearly evident in many of Sulivan's observations. Their work in the Falkland Islands perfectly encapulates the contrasting approaches of the two men. One of them, Darwin, was an 'ideas man' who famously described himself as a "sort of machine for observing facts and grinding out conclusions", and described his scientific approach as "grouping facts so that general laws or conclusions may be drawn from them”. The other, Sulivan, was an empiricist concerned to report what he saw accurately and in detail.

Though a perfectly adequate acknowledgement in formal terms, the text references and footnote in Darwin's 1846 paper do scant justice to Sulivan's contributions; but perhaps, by the time that Darwin received his insightful observations on Falkland Islands geology, the paper was nearly complete and Darwin's interests had moved on. Whatever the reason, Sulivan's contribution has remained generally unappreciated. A parallel can be drawn between this situation and the lack of credit given to Sulivan for his discovery in 1845, whilst in command of HMS Philomel, of fossil vertebrates in Tertiary strata at Santa Cruz on the coast of Patagonia. The circumstances of this discovery and its aftermath have been reviewed by Brinkman (2003). But at least it might be claimed that in the Falkland Islands, Sulivan's geological interest actually saved his life. In Letter 675 he told Darwin of an incident on an island ('Eagle Island', Speedwell Island in modern terms) where feral pigs were present. 
I had rather a formidable encounter with one large boar, \& had to thank my being a little bit of a geologist for my victory for holding him cheap and getting in his path after putting my two dogs to flight he made at me and tho I put a ball through him and a charge of small shot in his face he still came at me till just as he got within two feet and was jumping over a bunch of tussac ${ }^{2}$ I recollected my Geological hammer in my belt and got it out in time to strike him so fairly on the Forehead that he fell dead.

Darwin's geological observations during the visits by HMS Beagle aimed to establish the succession and age of the strata, and the regional structure into which they had been deformed. His careful work along the north shore of Berkeley Sound correctly established that 'clay-slate' (Fox Bay Formation) overlay 'quartz rock' (Port Stephens Formation), and his fossil collection from the same section established the age of the 'clay-slate'. Elsewhere, the broad uniformity of the lithologies and the lack of fossils led to the conflation with those two units of similar-looking but younger strata, which in turn led to a misunderstanding of the large-scale, regional structure. The fossils collected along the northern shore of Berkeley Sound were probably regarded by Darwin as his greatest scientific prize from the Falkland Islands, and his interest in comparing fossil faunas of similar age from different parts of the world has been stressed by Herbert (2005, p. 301). Once back in Britain, the fossils were soon passed on to specialists for assessment, many losing their 'Beagle' numbers as they moved between museums and curators. In contrast, Darwin's collection of rock specimens from the Falklands remained in his possession, unremarked, until passed on, with labels intact, to the Sedgwick Museum after his death. It is perhaps noteworthy that the only one of the probably many specimens sent back from the Falklands by Sulivan that survives in a 'Darwin' museum collection is a fossil: NHM B.17821, Australocoelia palmata from Burnt Harbour, Saunders Island, West Falkland.

Of Sulivan's many geological observations, those from the Arrow survey voyage (1838-1839) fared best, particularly those that related to structural geology. He provided Darwin with detailed notes and numerous sketches of folded and cleaved strata, three of which Darwin reproduced in his 1846 paper, including the example reproduced here as Figure 8. At the time Darwin was at the forefront of research into the significance of tectonically imposed cleavage, so his description of Sulivan's record as a "new and interesting case" confirms the originality of the observation. Sulivan's Arrow sketches are packed with detail, which sometimes obscured rather than clarified the overall fold pattern (for example see Darwin 1846, Figure 7): he attempted to record in detail exactly what he saw. In contrast, Darwin's sketches are simplified, skeletal

Tussac $=$ Tussock Grass, Poa flabellata, then a common coastal plant in the Falkland Islands, now much reduced by over-grazing. 
representations of the principal structures (for example see Darwin 1846, Figures 2-4); he 'cut to the chase' and sketched his interpretation of the overall structure, ignoring minor complications in order to try to understand the big picture.

Notes on phenomena now identified as being of glacial or periglacial origin were provided by Sulivan from both the Arrow and Philomel survey voyages. Beyond the possible discussion of the periglacial stone runs with James Geikie, Darwin did not follow-up Sulivan's leads, perhaps because his previous attempt to interpret glacial features had not been particularly successful. In 1838 Darwin had travelled to Scotland to investigate the 'parallel roads', a series of extensive terrace features in Glen Roy. His interpretation of them as uplifted marine shorelines (Darwin 1839) was soon disproved and Darwin sadly acknowledged his efforts as "one long gigantic blunder". The subsequent re-visit to North Wales localities in 1842 had converted him, at least partially, to a belief in large scale glaciation as an explanation of landscape features such as rounded and striated rock bosses and relict moraine ridges, but in common with his contemporaries he did not recognise the glacial origin of cirques such as the one unknowingly described by Sulivan from Mount Adam. Darwin also maintained a belief in floating icebergs as the principal conveyors of erratic boulders, as made clear in his reinterpretation of the Welsh features (Darwin 1842b). Indeed, forty years later Darwin was complaining that in a recent paper Geikie (1882) underrated the importance of floating ice in explaining drift deposits (Letter 1377, Darwin to Daniel MacKintosh dated 28 February 1882). Hence it is no great surprise that he should dismiss Sulivan's account of the Hill Cove outcrop, now known to be a late Carboniferous or early Permian glacigenic diamictite (the Fitzroy Tillite Formation) as an 'ice formation' of relatively recent origin, brought ashore by the grounding of erratic-charged icebergs at a time of higher sea level. There is no reason to believe that Darwin ever changed his mind on this. Indeed, the apparent Falklands examples may well have reinforced his more general view. Roberts (2012) has suggested that Darwin's well-known attachment to the 'iceberg theory' delayed by many years the achievement by British geologists of a consensus on glaciation.

Arguably, Sulivan's most important and original addition to geological knowledge in the Falkland Islands was his recognition of the widespread presence of dolerite dykes in West Falkland. Notice of the discovery was sent by Sulivan in a letter dispatched from Montevideo early in 1845 which may not have reached Darwin for some considerable time. Darwin read his Falkland Islands geology paper at the Geological Society meeting on 25 March 1846; since the dykes were then only mentioned in a footnote to the subsequently published version, it would seem that that his paper (Darwin 1846) was most probably largely completed before the new information arrived. However, it may also be the case that there was little more that Darwin could do with the 
news. Though Sulivan would almost certainly have dispatched specimens of the dykes it is not clear when or even whether they arrived; perhaps Darwin was simply being cautious.

In truth, it is quite likely that by the time Sulivan's geological observations reached Darwin from the Falkland Islands the latter's interests had moved on, leaving him with little inclination to pursue topics that were increasingly peripheral to his main research themes. The Philomel letters in particular, which would have arrived between 1843 and 1845, came at a pivotal period in Darwin's life (see for example Desmond and Moore 1991, Chapter 21). His thoughts on natural selection and the mutability of species had developed to the point that he was confiding his ideas to trusted friends, with caveats such as the famous "it is like confessing a murder" (letter to J. D. Hooker, 11 January 1844). Through the early part of 1844 Darwin wrote up his ideas into the 189page essay that he later in the year entrusted to his wife with instructions that it should be published in the event of his premature death. Then, in the summer, he started work on his third geological book based on the Beagle voyage: Geological Observations in South America (published in 1846). Intellectual turmoil was created in October 1844 by the anonymous publication of the notorious Vestiges of the Natural History of Creation, the furious reaction to which must have seriously worried Darwin as he contemplated publishing his own ideas. In the following year, 1845, Darwin was forced to interrupt work on Geological Observations on South America to produce a revised edition of his 1839 Journal of Researches from the Beagle voyage - and all the while he was marshalling ideas on natural selection and maintaining a prodigious correspondence. On top of everything else, in 1846 Darwin commenced his epic work on barnacles. This punishing schedule, coupled with his unpredictable state of health, would seem ample excuse for Darwin's putting aside Sulivan's geological notes from the Falkland Islands. He simply did not have the time to pursue the matters raised.

\section{ACKNOWLEDGEMENTS}

The extracts from Sulivan's letters are reproduced with the permission of Cambridge University Press and the Syndics of Cambridge University Library. For their assistance in locating specimens we thank the following: Sarah Long, Claire Mellish and Jonathon Todd (The Natural History Museum, London); Dan Pemberton and Matt Riley (The Sedgwick Museum, Cambridge); Matt Riley also facilitated photography of the 'Gorgonia' specimens. Thanks are also due to Lisa Di Tommaso of the NHM Earth Science Library for assistance in tracking down references and manuscript material, and to Sandy Henderson and Brian McIntyre (both BGS Edinburgh) for assistance in the preparation of the figures. Helpful reviews were provided by Don Aldiss, Sandra Herbert and Nigel Trewin, for which we are most grateful; we also acknowledge the editorial 
advice and assistance of David Oldroyd. PS thanks the staff of the Department of Mineral Resources, Stanley, for their support in the Falkland Islands. The paper is published by permission of the Executive Director, British Geological Survey (NERC).

\section{ARCHIVES}

In this paper, for convenience, Sulivan's letters have been identified by their reference number in Burkhardt and Smith $(1986,1987)$ and the on-line Darwin Correspondence Project Database (http://www.darwinproject.ac.uk). These numbers relate to class-marks in the Cambridge University Library manuscript archive as follows:

Letter 429 . . . CUL.DAR 39: 18-19

Letter 675 . . . CUL.DAR 39: 26-27 and 66-67; CUL.DAR 46.1: 70-74

Letter 730 . . . CUL.DAR 46.1: 75-86a

Letter 886 . . . CUL.DAR 46.1: 87-88

Letter 13,847 ... CUL.DAR 39: 20-25

The entries in Darwin's geological diary relevant to the Falkland Islands have the following class marks: CUL.DAR 32.123-152; CUL.DAR 33.165-222; CUL.DAR 34.65-86.

The details of the specimen collections held by The Natural History Museum, London, and The Sedgwick Museum, Cambridge, are given in appendices 1 and 2 respectively.

\section{REFERENCES}

Adie, R. J. 1952. The position of the Falkland Islands in a reconstruction of Gondwanaland. Geological Magazine 89: 401-410.

Adie, R. J. 1958. Falkland Islands (Iles Malouines ou Falkland: Islas Malvinas). Lexique stratigraphique international 5 (Amerique Latine): 35-55.

Aldiss, D. T. and Edwards, E. J. 1998. Geological Map of the Falkland Islands. Solid Geology, East and West Sheets, 1: 250000 Scale. British Geological Survey for Falkland Islands Government.

Aldiss, D. T. and Edwards, E. J. 1999. The geology of the Falkland Islands. British Geological Survey Technical Report WC/99/10. 135 pp.

Anderson, L. I. 2009. The Sedgwick Museum: Darwin's geological specimens. In: A Voyage Round the World, edited by A. M. Pearn, 68-71. Cambridge: Cambridge University Press.

Andersson, J. G. 1906. Solifluction, a component of subaërial denudation. Journal of Geology 14: 91-112.

Andersson, J. G. 1907. Contributions to the geology of the Falkland Islands. Wissenschaftliche Ergebnisse der Schwedischen Sudpolar-expedition 1901-1903 3 (Lieferung 2): 1-38. 
Armstrong, P. 1992. Darwin's Desolote Islands: A Naturalist in the Falklands, 1833 and 1834. Chippenham: Picton Publishing.

Baker, H. A. 1924. Final Report on Geological Investigations in the Falkland Islands, 1920-1922. Stanley: Government Printer.

Brinkman, P. 2003. Bartholomew James Sulivan's discovery of fossil vertebrates in the Tertiary beds of Patagonia. Archives of Natural History 30: 56-74.

Burkhardt, F. and Smith, S. (eds). 1986. The Correspondence of Charles Darwin 2 (1837 to 1843). Cambridge: Cambridge University Press.

Burkhardt, F. and Smith, S. (eds). 1987. The Correspondence of Charles Darwin 3 (1844 to 1846). Cambridge: Cambridge University Press.

Cawkell, M. 2001. The History of the Falkland Islands. Oswestry, Shropshire: Anthony Nelson.

Clapperton, C. M. 1971. Evidence of cirque glaciation in the Falkland Islands. Journal of Glaciology 10: 121-125.

Clarke, J. M. 1913. Fósseis Devonianos do Paraná. Monographia do Serviço Geológico y Mineralógico do Brasil 1: 1-353.

Darwin, C. R. 1839. Journal of Researches into the Geology and Natural History of the Various Countries visited by H. M. S. Beagle. London: Henry Colburn.

Darwin, C. R. 1842a. On the distribution of the erratic boulders and on the contemporaneous unstratified deposits of South America. Transactions of the Geological Society of London 6: 415-431.

Darwin, C. R. 1842b. Notes on the effects produced by the ancient glaciers of Caernarvonshire, and on the boulders transported by floating ice. Edinburgh New Philosophical Journal 33: 352-363.

Darwin, C. R. 1846. On the geology of the Falkland Islands. Quarterly Journal of the Geological Society of London 2: 267-274.

David, A. 2008. Sir B. J. Sulivan. In: The Dictionary of Falklands Biography (including South Georgia). From Discovery up to 1981, edited by D. Tatham, 523-525. Ledbury, Herefordshire: David Tatham.

Desmond, A and Moore, J. 1991. Darwin. London: Michael Joseph.

Dodds, M. J. 1969. An essay on the stone runs of Mount Usborne. The Falkland Islands Journal 1: 39-43.

Frakes, L. A. and Crowell, J. C. 1967. Facies and paleogeography of Late Paleozoic diamictite, Falkland Islands. Geological Society of America Bulletin 78: 37-58.

Geikie, J. 1881. Prehistoric Europe. London: Edward Stanford.

Geikie, J. 1882. Intercrossing of erratics. Scottish Naturalist 6: 193-200, 241254.

Geikie, J. 1894. The Great Ice Age. $3^{\text {rd }}$ edition. London: Edward Stanford.

Greenway, M. E. 1972. The geology of the Falkland Islands. British Antarctic Survey Scientific Reports 76: 1-42. 
Halle, T. G. 1911. On the geological structure and history of the Falkland Islands. Bulletin of the Geological Institution of the University of Uppsala 11: 115-229.

Herbert, S. 2005. Charles Darwin, Geologist. Ithaca and London, Cornell University Press.

Hunter, M. A. and Lomas, S. A. 2003. Reconstructing the Siluro-Devonian coastline of Gondwana: insights from the sedimentology of the Port Stephens Formation, Falkland Islands. Journal of the Geological Society, London 160: 459-476.

Limarino, C. O., Massabie, A., Rossello, E., López Gamundi, O., Page, R. and Jalfin, G. 1999. El Palaeozoico de Ventania, Patagonia e Islas Malvinas: área de las Islas Malvinas. In: Geología Argentina, edited by R. Caminos, 337-341. Buenos Aires: Instituto de Geología y Recursos Minerales,

Mendía J. E., Anselmi, G. and Negro, C. 2008. Las Islas Malvinas. In: Sitios de Interés Geológico de la República Argentina, Anales 46, II-Sur, edited by Comisión Sitios de Interés Geológico de la República Argentina, 875-889. Buenos Aires: Instituto de Geológia y Recursos Minerales, Servicio Geológico Minero Argentino.

Mitchell, C., Taylor, G. K., Cox, K. G. and Shaw, J. 1986. Are the Falkland Islands a rotated microplate? Nature 319: 131-134.

Morris, J. and Sharpe, D. 1846. Description of eight species of brachiopodous shells from the Palaeozoic rocks of the Falkland Islands. Quarterly Journal of the Geological Society of London 2: 274-278.

Murchison, R. I. 1859. Siluria: The History of the Oldest Fossiliferous Rocks and Their Foundations. $3^{\text {rd }}$ edn. London: John Murray.

Permanent Committee on Geographical Names, The. 2006. The Toponymy of the Falkland Islands as Recorded on Maps and in Gazetteers. www.pcgn.org.uk/Falkland\%20Islands-July2006.

Pernety, Dom A. J. 1771. The History of a Voyage to the Malouine (or Falkland) Islands, Under the Conmmand of M. de Bougainville, In Order to Form a Settlement There. Translated from the French of Dom Pernety's Historical Journal (1770). London: T. Jefferys.

Richards, P. C., Stone, P., Kimbell, G. S., McIntosh, W. C. and Phillips, E. R. 2013. Mesozoic magmatism in the Falkland Islands (South Atlantic) and their offshore sedimentary basins. Journal of Petroleum Geology 36: 6174.

Roberts, M. B. 2012. Buckland, Darwin and the attempted recognition of an Ice Age in Wales, 1837-1842. Proceedings of the Geologists' Association 123: 649-662.

Scasso, R. A. and Mendía, J. E. 1985. Rasgos estratigraficos y paleoambiantales del paleozoico de las Islas Malvinas. Revista Asociación Geólogica Argentina 40: 26-50.

Sharpe, D. 1847. On slaty cleavage. Quarterly Journal of the Geological Society of London 3: 74-105. 
Stone, P., Aldiss, D. A. and Edwards, E. J. 2005. Rocks and Fossils of the Falkland Islands. Keyworth, Nottingham: British Geological Survey for Department of Mineral Resources, Falkland Islands Government.

Stone, P. and Rushton, A. W. A. 2012. The pedigree and influence of fossil collections from the Falkland Islands: from Charles Darwin to continental drift. Proceedings of the Geologists’ Association 123: 520-532.

Stone, P. and Thomson, M. R. A. 2005. Archaeocyathan limestone blocks of likely Antarctic origin in Gondwanan tillite from the Falkland Islands. In: Terrane Processes at the Margins of Gondwana, Geological Society, London, Special Publications 246, edited by A. P. M. Vaughan, P. T. Leat and R. J. Pankhurst, 347-357. London: The Geological Society.

Stone, P., Thomson, M. R. A. and Rushton, A. W. A. 2012 (for 2011). An Early Cambrian archaeocyath-trilobite fauna in limestone erratics from the Upper Carboniferous Fitzroy Tillite Formation, Falkland Islands. Earth and Environmental Science Transactions of the Royal Society of Edinburgh 102: 201-225.

Stone, P., Richards, P. C., Kimbell, G. S., Esser, R. P. and Reeves, D. 2008. Cretaceous dykes discovered in the Falkland Islands: implications for regional tectonics. Journal of the Geological Society, London 165: 1-4.

Sulivan, H. N. 1896. Life and Letters of the Late Admiral Sir Bartholomew James Sulivan KCB, 1810-1890. London: John Murray.

Sulivan, H. N. 1890. Obituary: Admiral Sir B. J. Sulivan, K. C. B. Proceedings of the Royal Geographical Society and Monthly Record of Geography 12: 113-114.

Thomson, C. W. 1877. The voyage of the Challenger: The Atlantic 2. London: Macmillan.

Trewin, N. H., Macdonald, D. I. M. \& Thomas, C. G. C. 2002. Stratigraphy and sedimentology of the Permian of the Falkland Islands: lithostratigraphic and palaeoenvironmental links with South Africa. Journal of the Geological Society, London 159: 5-19.

Turner, J. C. M. 1980. Islas Malvinas. Segundo Simposio de Geología Regional Argentina, Cordoba 2: 1503-1527.

van Whye, J (ed.). 2002. The Complete Work of Charles Darwin Online. http://darwin-online.org.uk.

\section{APPENDIX 1}

CHARLES DARWIN'S GEOLOGICAL SPECIMENS FROM THE FALKLAND ISLANDS NOW HELD BY THE NATURAL HISTORY MUSEUM, LONDON.

\section{Darwin specimens from the Morris Collection}


49933. There are three specimens with Schellwienella sulivani and Australocoelia palmata with labels from the Morris Collection. The Natural History Museum (NHM) register lists 49933 and 49934 as arriving in 1867, but all three specimens carry the number 49933. Re-associated with the Darwin Collection on the latter's arrival at the NHM in 1880. Two of the specimens are illustrated in Figure 4.

\section{Darwin specimens from the Museum of Practical Geology}

Most of Darwin's fossil collection from the Falkland Islands was transferred to the NHM from the Museum of Practical Geology (MPG) in 1880. All of the specimens were collected from the shores of Berkeley Sound, East Falkland:

B.15639. Protoleptostrophia concinna, figured by Morris and Sharpe (1846) in Plate 10, Figures 2a, b, part and counterpart mounted together on a tablet.

B.15640. Orbiculoidea, figured by Morris and Sharpe in Plate 10, Figure. 5. Mounted on a tablet.

B.15641. "Spirifer" recorded in the NHM register but only doubtfully assigned to the Darwin Collection. We have not located this specimen.

B.15642. A blank entry in the NHM register, only doubtfully assigned to the Darwin Collection. We have not located a specimen carrying this number.

B.15643. A blank entry in the NHM register, only doubtfully assigned to the Darwin Collection. We have not located a specimen carrying this number.

B.15644. A. palmata.

[B.15645 - B.15655. Malvinokaffric brachiopod specimens from Bolivia. Not part of the Darwin collection.]

B.15656. S. sulivani, one specimen figured by Morris and Sharpe in Plate 10, Figure 1d, mounted on a tablet, but separately there are four other cut pieces with $S$. sulivani and A. palmata, one of which carries Darwin's red label number 908.

B.15657. Several impressions of A. palmata and one small belerophontid gastropod (probably Plectonotus sp.) that has not been previously recorded.

B.15658. A. palmata.

B.17789. S. sulivani, figured by Morris and Sharpe in Plate 10, Figure $1 \mathrm{a}$. Mounted on a tablet with B.17790.

B.17790. S. sulivani, figured by Morris and Sharpe in Plate 10, Figure 1b, Australospirifer and A. palmata; also present is the impression of a calmoniid trilobite thorax. Darwin's red label number 113. Mounted on a tablet with B.17789. 
B.17791. A. palmata figured by Morris and Sharpe in Plate 10, Figures 3a, 3c, 3d, and S. sulivani. Illustrated in Stone et al. (2005), Figure 11. Mounted on a tablet with one of two specimens numbered B.17796.

B.17792. Pleurochonetes falklandicus figured by Morris and Sharpe in Plate 10, Figure 4a. Darwin's red label number 101. Inscribed 'Falkland Isle' in black ink, hand-written. Mounted on a tablet.

B.17793. P. falklandicus figured by Morris and Sharpe in Plate 10, Figure 4d; an extra number, BC6662, has been added against a S. sulivani. Mounted on a tablet. There are in addition three further specimens with sawn faces that are also numbered B.17793 and show S. sulivani, one is inscribed 'Falkland I's' in black ink, hand-written.

B.17794. S. sulivani figured by Morris and Sharpe in Plate 10, Figure 1c, and Australospirifer figured in Plate 11, figs 1a, b, also crinoids. A second number, BD6660-1 has been added recently. Darwin's red label number 122. Illustrated in Stone and Rushton (2012) Figure 2. Mounted on a tablet.

B.17795. Australospirifer figured by Morris and Sharpe in Plate 11, Figure 2a.

Darwin's red label number 116. Mounted on a tablet with one of two specimens numbered B.17796.

B.17796. Australospirifer figured by Morris and Sharpe in Plate 11, Figure 2b.

Mounted on a tablet with B. 17795 . The number B.17796 also occurs on a specimen showing A. palmata that is mounted on a tablet alongside B.17791. The original specimen was probably divided by species.

B.17797. Australospirifer figured by Morris and Sharpe in Plate 11, Figure 3c.

Darwin's red label number 107. Mounted on a tablet with B.17798.

B.17798. Australospirifer figured by Morris and Sharpe in Plate 11, Figure 3a.

Darwin's red label number 105. Mounted on a tablet with B.17797.

B.17799. Orthis tenuis figured by Morris and Sharpe in Plate 11, Figure 4a and A. palmata. Mounted on a tablet with B.17800, which is the counterpart.

B.17800. O. tenuis figured by Morris and Sharpe in Plate 11, Figure 4b, with $A$. palmata. This specimen is in two pieces and is the counterpart of B.17799, with which it is mounted on a tablet.

B.17801. A. palmata and Australospirifer. This specimen is not specifically identified as being part of the Darwin collection.

B.17802. O. tenuis, A. palmata and crinoids.

B.17803. Australospirifer.

B.17804. O. tenuis, A. palmata, possibly S. sulivani, and crinoids

B.17805. S. sulivani. The counterpart is numbered B.17813.

B.17806. $P$. falklandicus.

B.17807. O. tenuis. A poor, rather deformed specimen.

B.17808. A. palmata.

B.17809. S. sulivani, Australospirifer and crinoids. Markedly deformed.

B.17810. Australospirifer.

B.17811. A. palmata. 
B.17812. P. falklandicus?

B.17813. S. sulivani. Counterpart of B.17805.

B.17814. O. tenuis.

B.17815. O. tenuis, A. palmata and crinoids. A poor, rather deformed specimen.

B.17816. $P$ falklandicus.

B.17817. Australospirifer and fragments of S. sulivani.

[B.17818-B.17820. Malvinokaffric brachiopod specimens from Bolivia. Not part of the Darwin collection.]

B.17821. A. palmata figured by Morris and Sharpe in Plate 10, Figure 3b. This is the specimen collected by Bartholomew Sulivan at Burnt Harbour, West Falkland. Illustrated in Stone and Rushton (2012, Figure 3). Mounted on a tablet.

B.40919. Australospirifer and P. falklandicus. This slightly worn specimen from Berkeley Sound came from the Geological Society in 1911, at the same time as the Sharpe Collection. It is quite deformed, consistent with a handwritten, white label which reads "Berkeley Sound - Falkland Islands". It is not identified as such but may be ex-Darwin.

\section{Darwin specimens within the Sharpe Collection}

B.56251-B.56257 . . . Australocoelia palmata

B.56258-B.56264 . . . Schellwienella sulivani

B.56265-B.56268 . . . Australostrophia mesembria (or Orthis tenuis?)

B.56269-B.56275 . . . Protoleptostrophia concinna

B.56276-B.56280 . . . Pleurochonetes falklandicus

\section{APPENDIX 2}

\section{CHARLES DARWIN'S GEOLOGICAL SPECIMENS FROM THE FALKLAND ISLANDS NOW HELD BY THE SEDGWICK MUSEUM, CAMBRIDGE.}

\section{Fossil specimens}

The fossil specimens held by the Sedgwick Museum (SM) were presented to Cambridge University by George H. Darwin in January 1897 after his father's death. They are listed below under their SM registered numbers; None of Darwin's original red labels survive and only two of his original 'red series' numbers can be identified (shown bold), now recorded on replacement green labels. Note that Schellwienella sulivani is described in the SM register as Orthotetes sulivani. 
X21401-21403. Schellwienella sulivani.

X21404-21406. Australocoelia palmata. (These six numbers are assigned to shells on a single specimen, mounted on a tablet. All are described as 'topotypes'. Berkeley Sound, East Falkland.)

X21407. A. palmata.

X21408. S. sulivani. (The numbers X21407 and X21408 are assigned to shells on the same specimen, which is mounted on a tablet along with a second specimen but providing no locality details).

X21409. S. sulivani.

X21410-21412. (These three numbers refer to partial impressions of S. sulivani on the same specimen, which also carries numerous crinoid impressions. The specimen carries Darwin's number 1096 on a SM green 'Beagle Collection' label. Berkeley Sound, East Falkland.)

Not registered: two specimens showing S. sulivani mounted together on the same tablet. Falkland Islands.

Not registered: two specimens mounted together on the same tablet and showing poor, rather deformed examples of $P$. falklandicus and $A$. palmata with a few crinoid ossicles. One of the specimens carries Darwin's number 1125 on a SM green 'Beagle Collection’ label.

Not registered: five small sandstone fragments showing pieces of crinoid, all mounted on one tablet. The accompanying note states: "Lower Devonian, Beagle Voyage”.

\section{Rock specimens}

The rock specimens held by the Sedgwick Museum were also presented to Cambridge University by George H. Darwin in January 1897 after his father's death. Darwin's original labels have all been replaced by green 'Beagle Collection' labels but the original four-figure number is preserved. All but one are from Darwin's red series, the exception, the highest-numbered specimen, is from the green series. Darwin's 4-figure number, as recorded on the replacement labels, is shown below in bold, following the 5- or 6-figure SM (Harker Collection) number. Specimens are listed in the sequence of their Darwin numbers, shown in bold type.

112143-1078. North side of Berkeley Sound, East Falkland. Port Stephens Formation, pale grey, quartzo-feldspathic sandstone.

112144-1079. North side of Berkeley Sound, East Falkland. Port Stephens Formation, pale grey-brown, quartzo-feldspathic sandstone with dark, cross laminae. Described by Darwin as 'quartz-rock'. 
112145-1080. North side of Berkeley Sound, East Falkland. Fault breccia of Port Stephens Formation quartzo-feldspathic sandstone.

112146-1081. Johnson's Creek (sic, probably = Johnson Harbour), East Falkland. Port Stephens Formation, pale brown quartzo-feldspathic sandstone.

112147-1082. Johnson's Creek (sic, probably = Johnson Harbour), East Falkland. Fox Bay Formation, cleaved, light brown mudstone. Described by Darwin as 'imperfect clay-slate'.

112148-1083. Johnson's Creek (sic, probably = Johnson Harbour), East Falkland. Fox Bay Formation. Cleaved, thinly interbedded dark mudstone and grey-green siltstone, possibly disrupted slightly by bioturbation.

112149-1084. South side of Berkeley Sound, East Falkland. Port Stanley Formation, pale grey quartzite. Described by Darwin as 'quartz-rock'.

112150-1085. South side of Berkeley Sound, East Falkland. Fox Bay Formation, dark grey, micaceous sandstone.

112152-1132. Two small pieces of peat.

112153-1133. South side of Berkeley Sound, East Falkland. Port Stanley Formation, pale grey quartzite with black flecks, possibly grains of rutile.

112154-1134. Only located as 'Falkland Islands' but notebook suggests 'main range of hills', East Falkland. Fault breccia, probably of Port Stanley Formation quartzite.

1121556-1135. South side of Berkeley Sound, East Falkland. Fox Bay Formation, dark grey siltstone.

112156-1136. North side of Berkeley Sound, East Falkland. Port Stephens Formation, white, quartzo-feldspathic sandstone.

112288-1886. New Island, West Falkland. Port Stephens Formation, pale grey, quartzo-feldspathic sandstone. Collected by William Kent.

112289-1887. New Island, West Falkland. Port Stephens Formation, pale grey, quartzo-feldspathic sandstone. Collected by William Kent.

112290-1888. New Island, West Falkland. This specimen was not seen because in 2012 it was on loan to the Open University-but almost certainly Port Stephens Formation, pale grey, quartzo-feldspathic sandstone. Collected by William Kent.

112291-1889. New Island, West Falkland. Port Stephens Formation, pale grey, quartzo-feldspathic sandstone. Collected by William Kent.

47134HS-1890. Near Cape Meredith, West Falkland. Port Stephens Formation, pale grey, quartzo-feldspathic sandstone. Collected by William Kent.

112292-1891. Near Cape Meredith, West Falkland. "Scoriae” - black, highly vesicular basalt lava 'picked up on beach', collected by William Kent. Not mentioned by Darwin and probably not local to the Falklands (very few of the Mesozoic dolerite dykes common in the southern part of West Falkland are vesicular). A note added to the label by Professor Alfred Harker (1859-1939) suggests that the rock fragment may have 'floated-in' from a volcanic Antarctic island. Pumice is common on Falklands shores 
but specimen 1891 is very fresh and also seems a little too dense to float very far.

47128HS-1892. “Main chain of hills”, East Falkland. Port Stanley Formation, white quartzite with black flecks, probably a mixture of very small mudstone clasts and detrital grains of rutile.

112293-1893. Johnson Harbour, East Falkland. Fox Bay Formation, brown sandstone.

112294-1894. Johnson Harbour, East Falkland. Fox Bay Formation, laminated sandstone and siltstone, micaceous.

112295-1895. Johnson Harbour, East Falkland. Pale grey quartzo-feldspathic sandstone, Port Stephens Formation.

112296-1896. Johnson Harbour, East Falkland. Fox Bay Formation, laminated sandstone and siltstone.

112297-1897. Johnson Harbour, East Falkland. Fox Bay Formation, finely interbedded sandstone and mudstone.

112299-1939. Johnson Harbour, East Falkland. Fox Bay Formation sandstone with sections of crinoid arms. Originally identified as 'Gorgonia', this name has been crossed out and replaced with 'Bryozoa'.

112300-1940. Johnson Harbour, East Falkland. Fox Bay Formation sandstone with sections of crinoid arms. Originally identified as 'Gorgonia', this name has been crossed out and replaced with 'Bryozoa'; on display in the Sedgwick Museum as crinoids.

112301?-1941. Johnson Harbour, East Falkland. Fox Bay Formation sandstone with sections of crinoid arms. Originally identified as 'Gorgonia', this name has been crossed out and replaced with 'Bryozoa'; on display in the Sedgwick Museum as crinoids. Illustrated in Figure 7.

112299?-1942. Johnson Harbour, East Falkland. Fox Bay Formation sandstone with sections of crinoid arms. Originally identified as 'Gorgonia', this name has been crossed out and replaced with 'Bryozoa'; on display in the Sedgwick Museum as crinoids. This specimen is the counterpart of 112299/1939. Illustrated in Figure 7.

112302-1943. Johnson Harbour, East Falkland. Fox Bay Formation sandstone with sections of crinoid arms. Originally identified as 'Gorgonia', this name has been crossed out and replaced with 'Bryozoa'; on display in the Sedgwick Museum as crinoids.

112303-1944. Johnson Harbour, East Falkland. Fox Bay Formation sandstone with sections of crinoid arms and pluricolumnals. Originally identified as 'Gorgonia', this name has been crossed out and replaced with 'Bryozoa'; on display in the Sedgwick Museum as crinoids.

(Darwin's notes suggest that specimen numbers 1945 and 1946 also showed 'Gorgonia', but these examples have not been identified.)

47138HS-2058. Port Egmont, Saunders Island, West Falkland. Fox Bay Formation, dark grey, micaceous sandstone. Collected by William Kent. 


\section{Figure Captions}

Figure 1.

Outline geology of the Falkland Islands showing the position of localities mentioned in the text. For details of the lithostratigraphy see Table 1.

Figure 2.

A view looking north across the settlement of Darwin towards Mount Usborne, $705 \mathrm{~m}$, the highest point in the Falkland Islands. The low-lying foreground is underlain by relatively soft, Permian sandstone and mudstone of the Lafonia Group. The distant hills are composed of hard, Devonian quartz-sandstone and quartzite of the Port Stanley Formation, West Falkland Group.

Figure 3.

The rugged topography of Darwin's “main range of hills” produced by the outcrop of the hard quartzite of the Port Stanley Formation; the view looks west towards the Wickham Heights from a position west of Stanley.

Figure 4.

Two of the three specimens of fossil brachiopods held by The Natural History Museum, London, which were collected by Darwin but carry labels from the Morris Collection. The prominent internal moulds are of Schellwienella sulivani (named after Bartholomew Sulivan), most of the smaller impressions are of Australocoelia palmata. B.49933. The Falkland Islands twenty-pence coin is 20 $\mathrm{mm}$ in diameter.

Figure 5.

Trace fossils, possibly a variety of Planolites, on a bedding surface from the Fox Bay Formation at Fox Bay. Similar occurrences may have resulted in Sulivan's report of "fossil worms" at White Rock Bay. The Falkland Islands two-pence coin is $25 \mathrm{~mm}$ in diameter.

Figure 6.

Trace fossils from the Fox Bay Formation at Port Howard that appear to show transverse and longitudinal sections through a possibly back-filled burrow.

Similar occurrences may have resulted in Sulivan's report of "fossil worms" at White Rock Bay. BGS specimen number LX1026.

Figure 7.

Examples of the fossil crinoid arms originally described by Darwin as 'Gorgonia', from the collection of the Sedgwick Museum, Cambridge: Darwin's Beagle specimen number 1941 (left); Darwin’s Beagle specimen number 1942 (right). 
Figure 8.

A sketch by Sulivan of folded and cleaved strata, probably in the vicinity of Fitzroy, East Falkland, as utilised by Darwin (1846, Figure 1) in his paper on the geology of the Falkland Islands.

Darwin's explanation reads as follows, following Sulivan's original notes: A, D, F. Beds of clay-slate, with cleavage-laminae perpendicular to the horizon; $\mathrm{E}$ and part of C. Similar beds, with the cleavage at right angles to every flexure; B and parts of C. Beds of imperfect, non-laminated clay-slate, with intercalated seams of sandstone represented by the dotted parts; F. Nucleus or core of clay-slate formed by the lateral crushing of the strata, about two feet high and one foot broad. These nuclei occur in almost all the folds.

Figure 9.

Sulivan's sketch of the glacial cirque on Mount Adam, West Falkland compared with the features shown on a modern topographic map.

a. The glacial cirques on Mount Adam and Shingly Mountain, West Falkland, as represented on DOS 453 (Series H791), Falkland Islands 1:50 000 Sheet 10, 1961; the area shown measures $6 \mathrm{~km}$ by $4.5 \mathrm{~km}$, heights in feet.

b. A copy of Sulivan's sketch map showing the glacial cirque on Mount Adam. 'Dip' probably refers to the topographical dip slope rather than to the dip of the strata, which in the Mt Adam area are mostly inclined gently towards the northeast. Sulivan's sketch is not topographically accurate, but the approximate area represented is outlined in Figure 9a. After Burkhardt and Smith (1986, p. 366).

Figure 10.

An aerial view of stone runs at the eastern end of the Wickham Heights, East Falkland, showing the characteristic linear stripes produced by periglacial sorting that were apparently first noted by Sulivan, who likened them to "the waves of the sea beach”. The field of view is approximately $300 \mathrm{~m}$ wide.

Figure 11.

Boulders of granite and quartzite weathering out of the Fitzroy Tillite Formation in a sea cliff near Hill Cove, West Falkland, exactly as described by Sulivan.

Figure 12.

Sulivan's sketches illustrating dolerite dykes seen in West Falkland. After Burkhardt and Smith (1987, p. 118).

a. The effect of thermal metamorphism altering and hardening the host sandstone (most probably from the Port Stephens Formation). Sulivan wrote: "[W]here the vein [dyke] had fallen out the two sides or walls of the crevice stuck up in this manner and were very much harder than the rest of the sandstone but only for two or three inches”. 
b. A dyke cutting obliquely across sandstone beds (most probably from the Port Stephens Formation) as seen in a small island off West Falkland. Sulivan wrote: " . . . the appearance of the island is like this the height of the cliff being about 100 feet and the vein [dyke] about 6 feet thick". 


\section{Table 1}

Lithostratigraphy of the West Falkland Group (Silurian to Devonian or earliest Carboniferous) and the Lafonia Group (Carboniferous to Permian). The maximum likely thickness of each formation is shown. After Aldiss and Edwards (1998, 1999), Trewin et al. (2002), and Hunter and Lomas (2003).

\begin{tabular}{|c|c|c|}
\hline Lithostratigraphy & Principal lithologies & $\begin{array}{l}\begin{array}{l}\text { Depositional } \\
\text { environments }\end{array} \\
\end{array}$ \\
\hline \multicolumn{3}{|l|}{ Lafonia Group } \\
\hline $\begin{array}{l}\text { Bay of Harbours Fm. } \\
(3,000 \mathrm{~m})\end{array}$ & Sandstone, mudstone & Delta top and channels \\
\hline $\begin{array}{l}\text { Brenton Loch Fm. } \\
(3,000 \mathrm{~m})\end{array}$ & $\begin{array}{l}\text { Sandstone, } \\
\text { laminated mudstone }\end{array}$ & $\begin{array}{l}\text { Deltaic and prodeltaic } \\
\text { basin floor }\end{array}$ \\
\hline $\begin{array}{l}\text { Port Sussex Fm. (400 } \\
\text { m) }\end{array}$ & $\begin{array}{l}\text { Mudstone, sandstone, } \\
\text { diamictite }\end{array}$ & $\begin{array}{l}\text { Glaciomarine to marine } \\
\text { or lacustrine }\end{array}$ \\
\hline $\begin{array}{l}\text { Fitzroy Tillite Fm. (850 } \\
\text { m) }\end{array}$ & Massive diamictite & Glacial and glaciomarine \\
\hline Bluff Cove Fm. (250 m) & Sandstone, mudstone & $\begin{array}{l}\text { Shallow marine or } \\
\text { proglacial deltaic }\end{array}$ \\
\hline & $\begin{array}{l}\text { Low-angle } \\
\text { unconformity }\end{array}$ & \\
\hline \multicolumn{3}{|l|}{ West Falkland Group } \\
\hline $\begin{array}{l}\text { Port Stanley Fm. (1,100 } \\
\text { m) }\end{array}$ & $\begin{array}{l}\text { Quartz-sandstone, } \\
\text { mudstone }\end{array}$ & $\begin{array}{l}\text { Shallow marine and } \\
\text { shoreface }\end{array}$ \\
\hline $\begin{array}{l}\text { Port Philomel Fm. (350 } \\
\text { m) }\end{array}$ & Sandstone, mudstone & Deltaic to shallow marine \\
\hline Fox Bay Fm. (1,500 m) & $\begin{array}{l}\text { Micaceous sandstone, } \\
\text { mudstone }\end{array}$ & $\begin{array}{l}\text { Marine inner shelf and } \\
\text { shoreface }\end{array}$ \\
\hline $\begin{array}{l}\text { Port Stephens Fm. } \\
(2,500 \mathrm{~m})\end{array}$ & $\begin{array}{l}\text { Quartzo-feldspathic } \\
\text { sandstone }\end{array}$ & $\begin{array}{l}\text { Fluvial to intertidal and } \\
\text { shoreface }\end{array}$ \\
\hline & $\begin{array}{l}\text { Major, angular } \\
\text { unconformity }\end{array}$ & \\
\hline $\begin{array}{l}\text { Cape Meredith } \\
\text { Complex }\end{array}$ & \multicolumn{2}{|c|}{$\begin{array}{l}\text { Proterozoic granite and gneiss, } \\
\text { ca } 1,000 \mathrm{Ma}\end{array}$} \\
\hline
\end{tabular}


Table 2.

Taxonomic nomenclature applied to Darwin's fossil brachiopods

Morris and Sharpe

(1846)

Orthis sulivani

Orthis concinna

Orthis tenuis

Atrypa palmata

Chonetes falklandica

Spirifer hawkinsii

Spirifer antarcticus

Spirifer orbignii

Orbicula (undetermined)
Clarke (1913)

Schuchertella sulivani Leptostrophia concinna

Leptocoelia flabellites

Chonetes falklandicus

Spirifer hawkinsii

Spirifer antarcticus

Orbiculoidea baini
Cocks cited in Aldiss and Edwards (1999)

Schellwienella sulivani

Protoleptostrophia concinna

Australostrophia mesembria?

Australocoelia palmata

Pleurochonetes

falklandicus

Australospirifer hawkinsii

Orbiculoidea falklandensis 


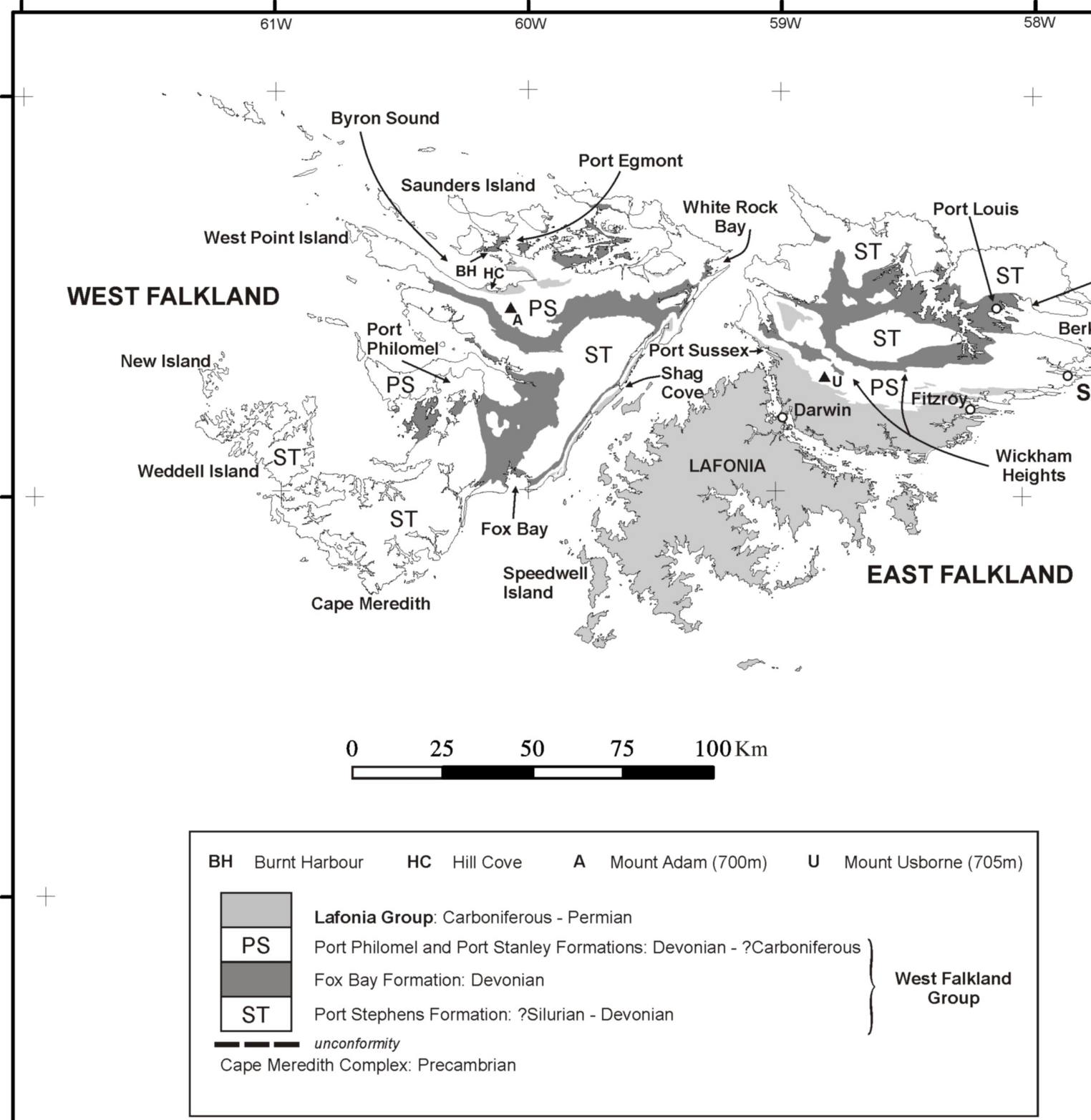

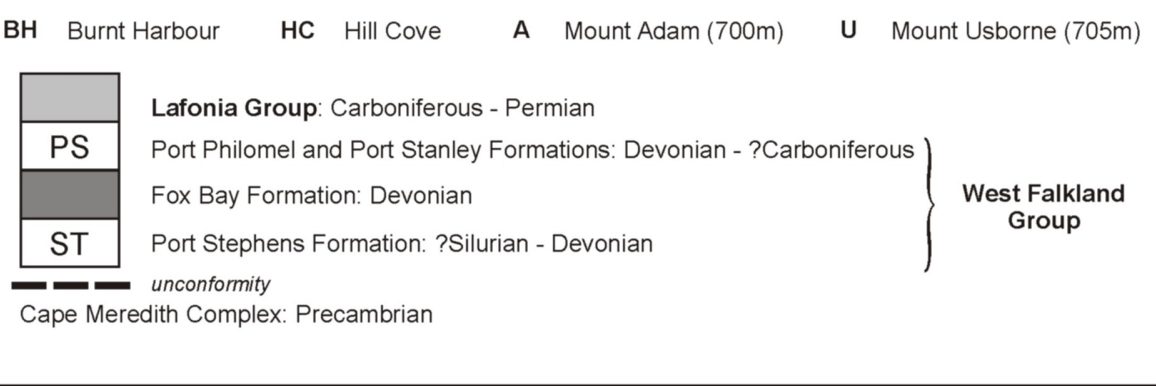




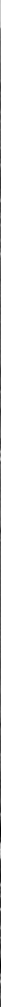




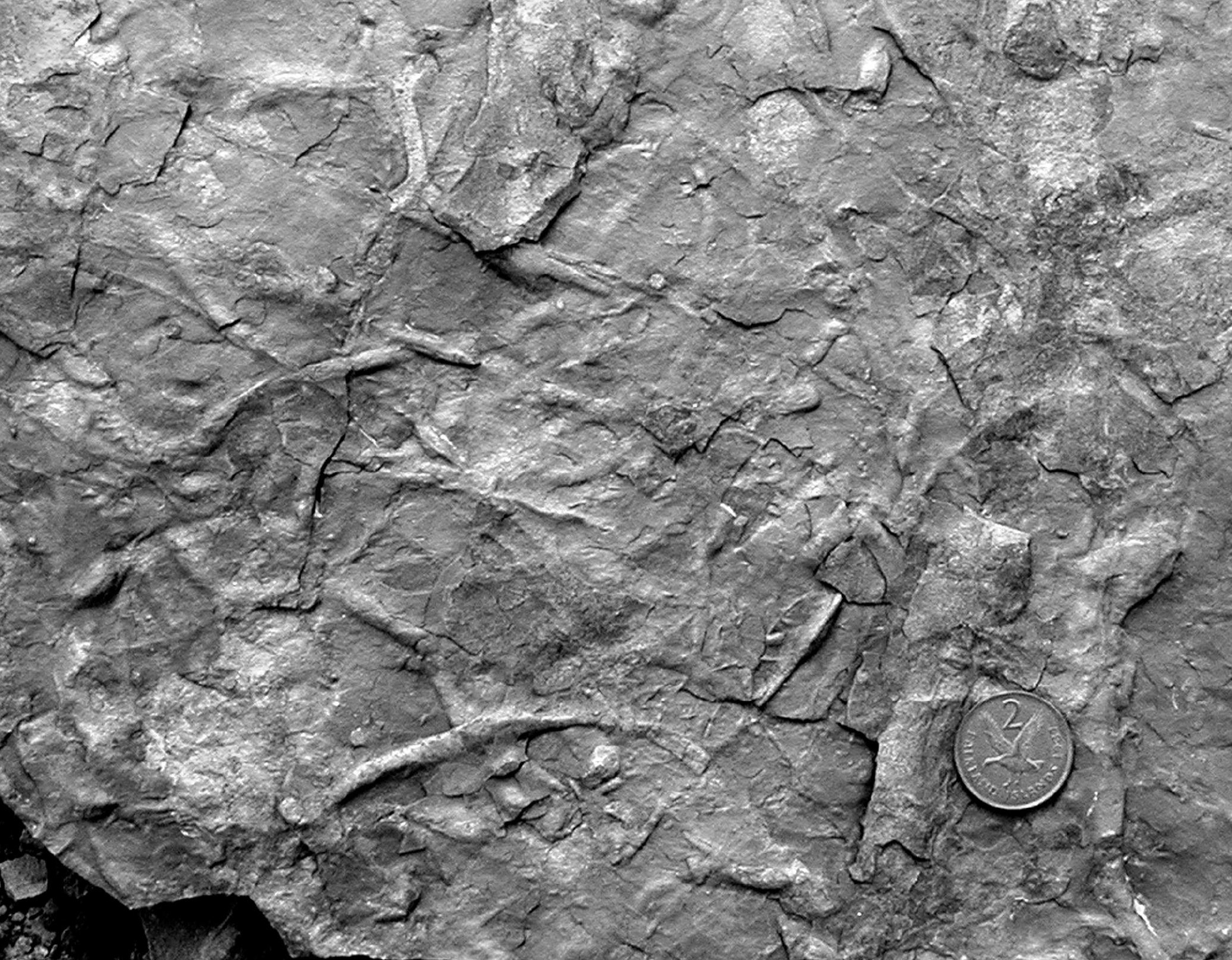




\section{$\ln (1)$}

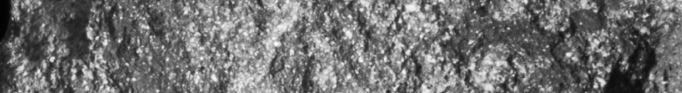

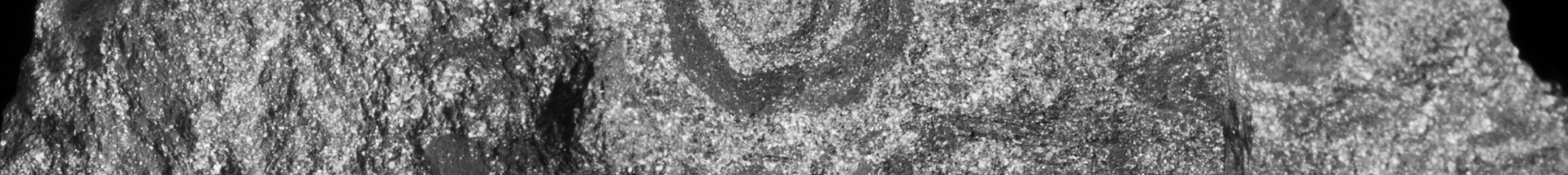

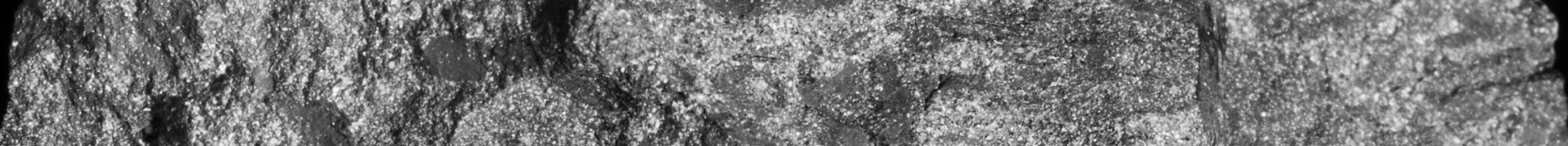

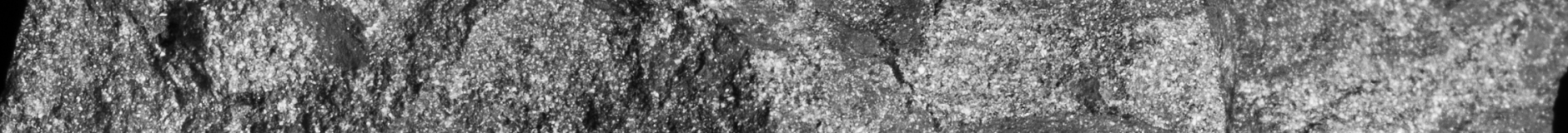

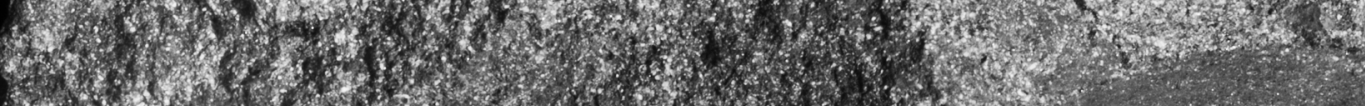

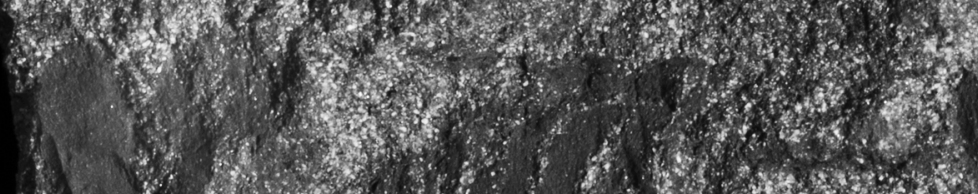

H.

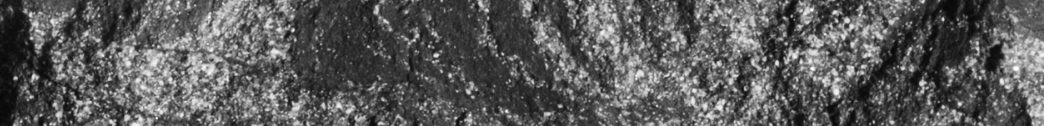
F,

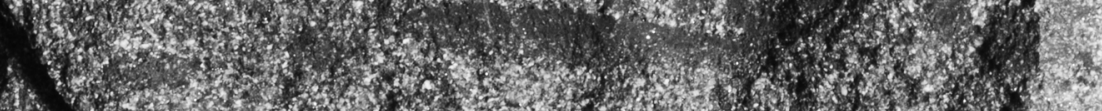
1. W.7.7. 


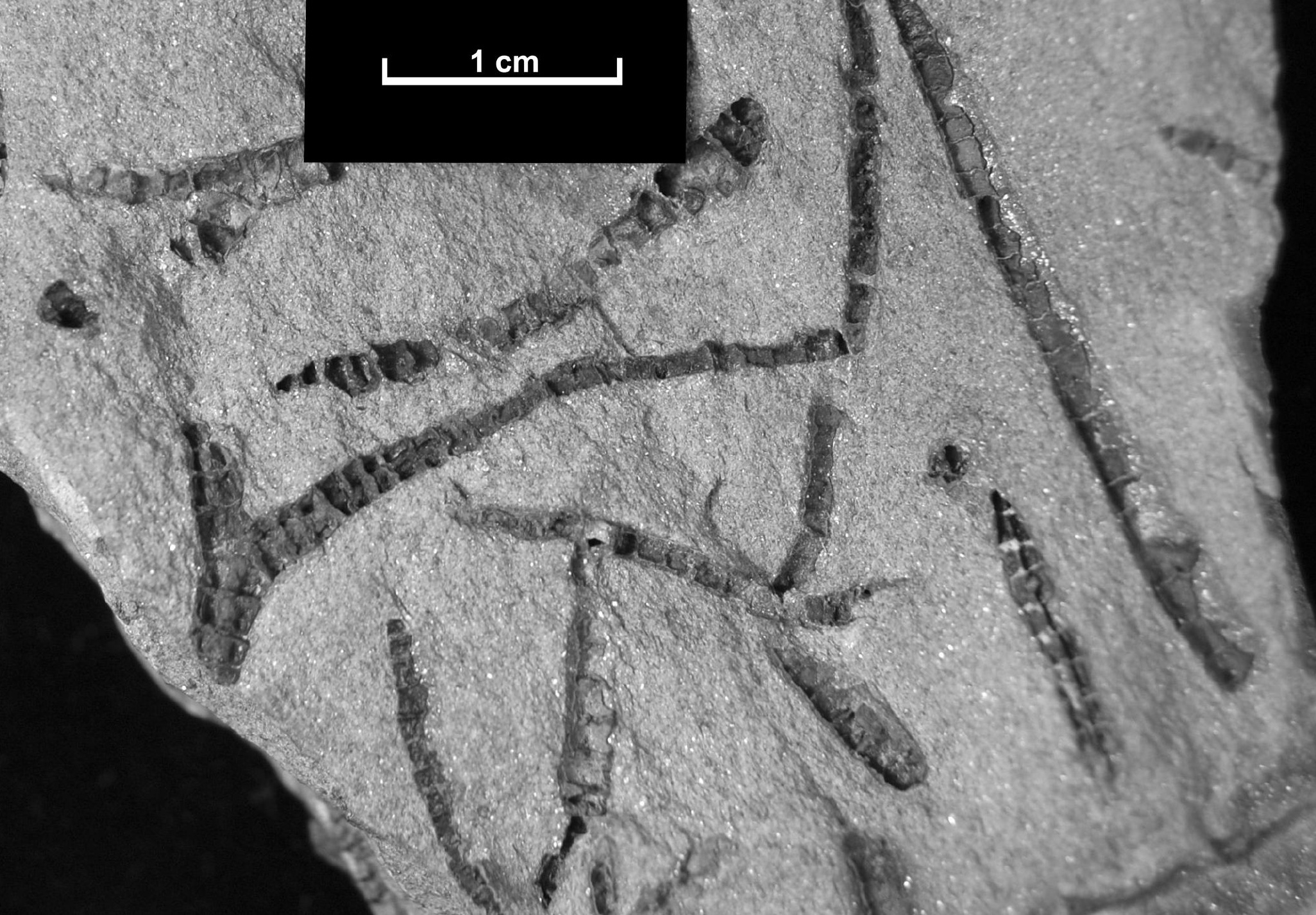




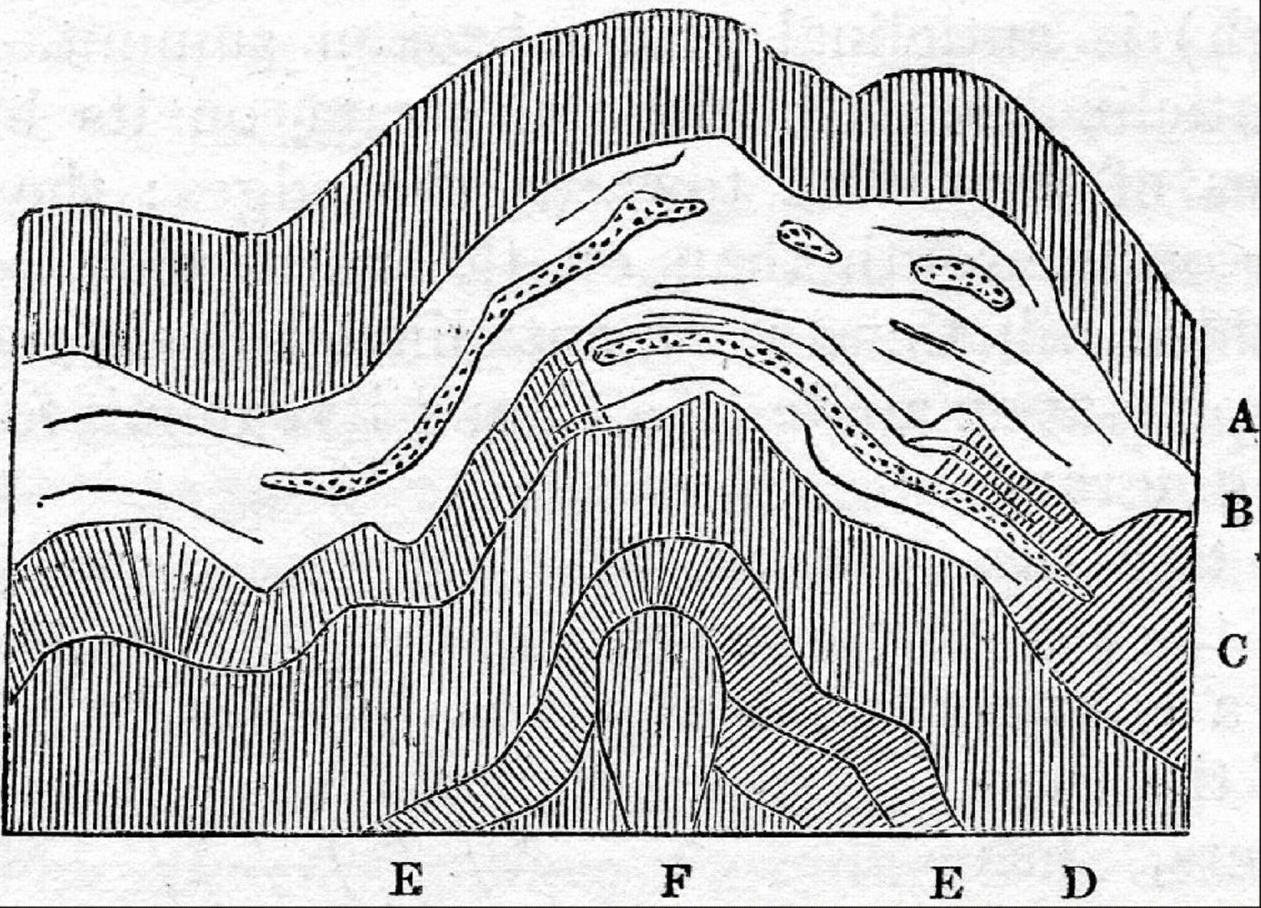




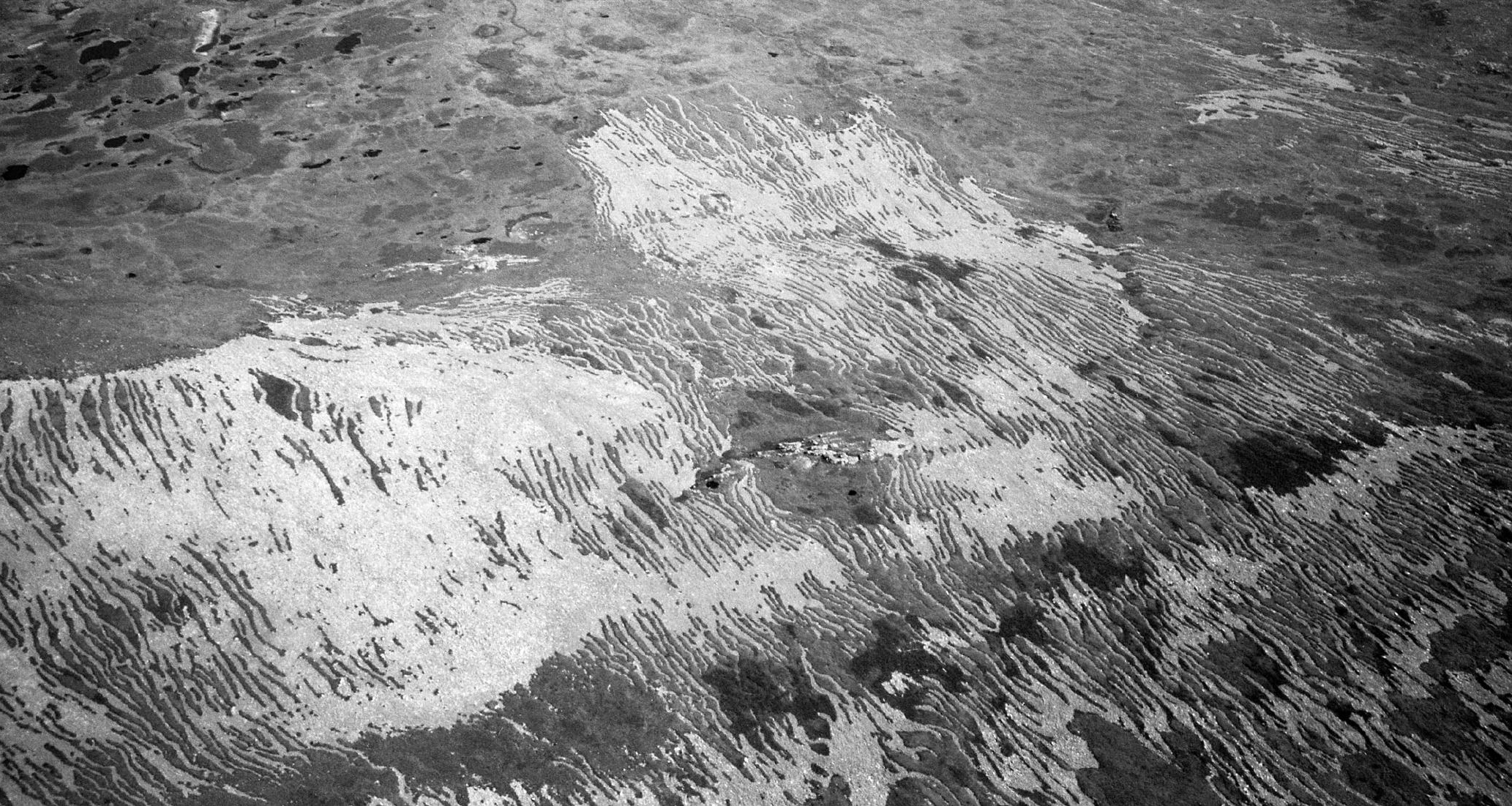




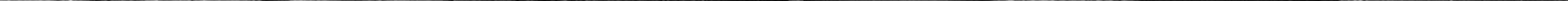




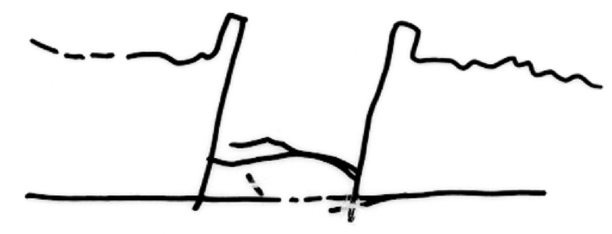

a

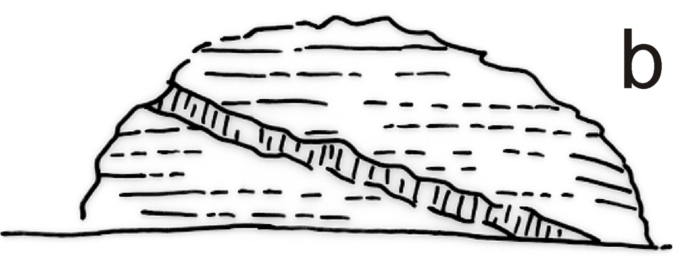

